\title{
DSM Pocket Guidebook
}

Volume 3: Agricultural Technologies

prepared by

Solar Energy Research Institute

1617 Cole Boulevard

Golden, Colorado 80401

(303) 231.7303

prepared for (under subcontract to)

Contract DE-1A65-90WA07253 with Western Area Power Administration 1627 Cole Boulevard, P.O. Box 3402

Golden, Colorado 80401

(303) 231.7504

Contract DE-AC02-83CH10093 with

U.S. Department of Energy Washington, D.C.

SERI/TP-254-4098C APRIL 1991 DE91002155 
TABLE OF CONTENTS

Briel \#

Page $\Lambda$

DISCLAIMER OF WARRANTY AND LIMITATION OF LIABILITY

This manual is provided "as is" without warranty of any kind, either expressed or implied, including but not limited to the implied warranties of merchantability and fitness for a particular purpose. The entire risk as to the quality, performance, and accuracy of the manual is with the holder. In no event will the authors be liable to the holder or any party to whom hoider distributes the manual for any damage, including but not limited to damages for any lost prolits, lost savings, or other incidental or consequential damages arising out of the use or inability to use the manual, oven if the author(s) have been advised of the possibility of such damage.

Printed in the United States of America

Available from National Technical Information Service

U.S. Department of Commerce

5285 Port Royal Road

Springtield, VA 2216!

Price: Microfiche A01 / Printed Copy A07

Codes are used for pricing all publications. The $\operatorname{cod} \theta$ is determined by the number of pages in the publication. Information pertaining to the pricing codes can be found in the current issue of the following publications which are generally available in most libraries: Energy Research Abstracts (ERA); Government Reports Announcements and Index (GRA and I) Sciendific and Technical Abstract Reports (STAR); and publication NTIS-PR-360 available from NTIS at the above address.
Introduction to Volume 3,

Agricultural Technologies ........... 1

IRRIGATION ............... 7

1 Alternative Irrigation Systems ......... 9

2 Irrigation Load Management ... . ...... 14

3 Pumping Plant Efticiency Improvement .. 16

4 Automation of Irrigation ............ 20

DAIRY FARM MEASURES . . . . . . . . 23 5 Ice-Bank vs. Direct-Expansion Milk Cooling 24

6 Partial In-Line Coolers or Prncoolers .... 27

7 Water Heating .................. 29

8 Waste Heal Recovery . . . . . . . . . . . . . 31

9 Vacuum Pumps ................, 36

10 Ventilation .................. 38

MATERIALS HANDLING $\ldots \ldots \ldots \ldots, 41$

11 Grain Conveyance .............. 42

12 Fead Processing ............... 44

13 Electric Chore Vehicles ...... . . . . . 47

CROP DRYING . . . . . . . . . . . 51

is Grain Drying with Low-Temperature

Electric ...................... 52

15 Grain Drying with Unheated Air . . . . . . . 54

16 Confrolled Aeration for Quality Grain . . . . 56

17 Hay Drying . . . . . . . . . . . . . . . . . . 58

LIVESTOCK MEASURES . . . . . . . . 61

18 Electric Brooding $\ldots \ldots \ldots \ldots \ldots \ldots, 62$

19 Dual Fuel for Livestock Brooding .......

20 Waterers ...................6.67

21 Earth-Tube Heat-Exchange Ventilation Systems ..................... 69

22 Controlled Ventilation ... ......... 71

23 Evaporative Cooling Systems . . . . . . . 73 


\section{ACKNOWLEDGMENTS}

The National Food and Energy Council (NFEC) with its allied organizations- the National Rural Electric Cooperative Association (NRECA) and the Edison Electric Institute (EEI)-has been instrumental in advaricing research in energy efficiency for the agricultural sector. The Electric Power Researcir Institute (EPRI) has been an active sponsor of their work Several NFEC documents are cited extensively 'in this volume of the DSM Pocket Guidebook and deserve special mention here.

- McFate, K. L., and B. A. Stout, eds., Electrical Energy in Agriculture, 1989, Amsterdam, Elsevier. - NFEC, 1986, Agricultural Technical Brief Notelbook, Pub. 8609, Columbia, MO.

- NFEC, 1986, Electric Farm Equipment Guide, Pub. 8610, Columbia, MO.

The NFEC can be contacted directly if you have any questions about these publications. The'- address is 409 Vandiver West, \#202, Columbia, MO 65202. Their telephone number is (314) $875-7155$.

\section{FOREWORD}

In previous years of low-cost energy, many dema side management (DSM) technologies simply w not cost effective. Today, however, with rising ene prices and the mandate to conserve, utility $D$; programs and advanced energy-efficient technolog offer utilities significant opportunity for econor means to reduce operating costs and shift or $d \epsilon$ load growth. Furthermore, recent developments DSM technologies have improved energy quality a reduced customer maintenance costs.

This series of guidebooks is intended as a tool utility personnel involved in DSM programs a services. Both the novice and the DSM expert $c$ benefit from the information compiled.

Efficient energy utilization through DSM applicatic helps Western meet one of its primary obji tives-elimination of wasteful energy practices a adoption of conservation programs that $\mathrm{mi}$ customer needs in an era of diminished resourc and increased environmental concerns. 


\section{PREFACE TO THE DSM POCKET GUIDEBOOK}

INTAODUCTON

It has been estimated that If electricity were used efficiently with commercially available onc technologies, $24 \%-44 \%$ of the nation's current der for electricity could be eliminated. Almost all I electric utilities in the west are investigating demand-side management (DSM) opportunitie! some service territories, for example, impr efficiency could soon produce as much power as from new coal-fired plants (Figure P.1) and produc a lower cost (Figure P-2). Even utilities that cur have excess capacity are finding that DSM offel opportunity to build efficient end-use stock to help meet their future load shape objectives.

Utility DSM programs typically consist of se measures designed to modify the utility's load shap example, innovative rate siructures, direct utility $\propto$ ol loads, promotion of energy-efficient lochnologies customer education). The coordinated implementati such measures requires planning, analysis of opl engineering, marketing, monitoring, and , coordination activities (Figure P-3). This guide addresses one facet of an overall DSM pros selection of end-use technologies within the elec utilitios.

\section{TECHNOLOGY SELECTION}

All tacels of a utility's DSM program, incli technology selection, must be planned with the ut overall objectives in mind. Selected technologies make the utility better able to serve its custome: providing low-cost reliable power. Yet the utility also be able to recover its fixed and operating cos 


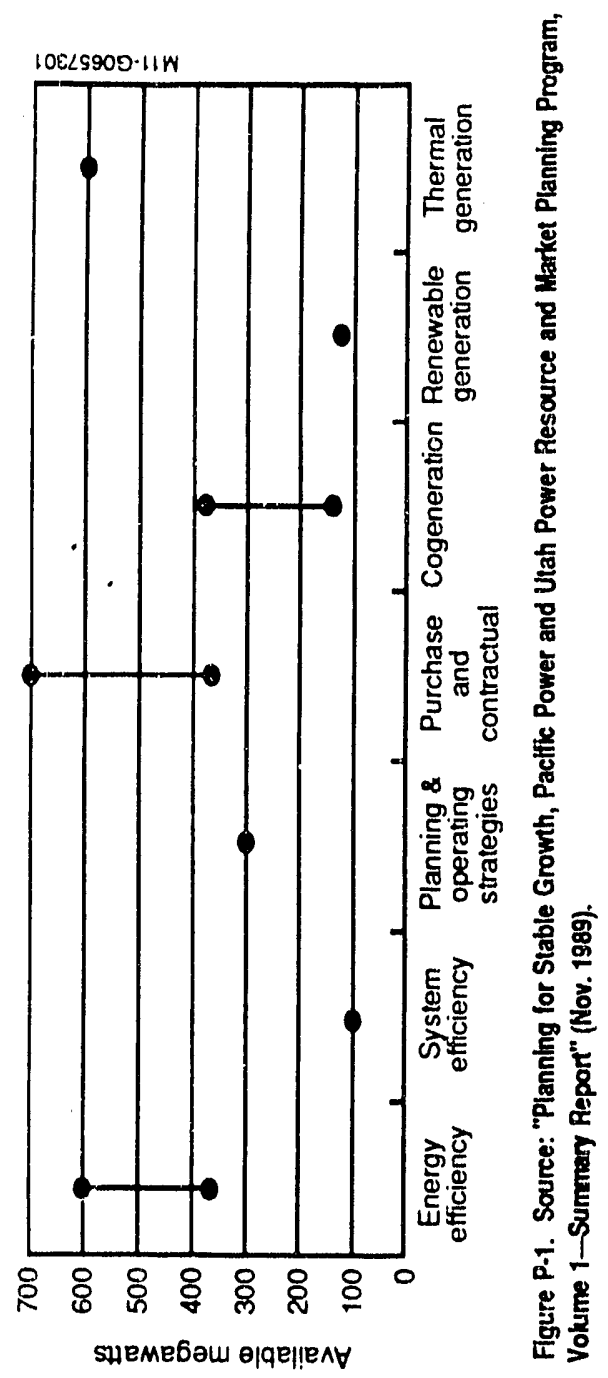

viii

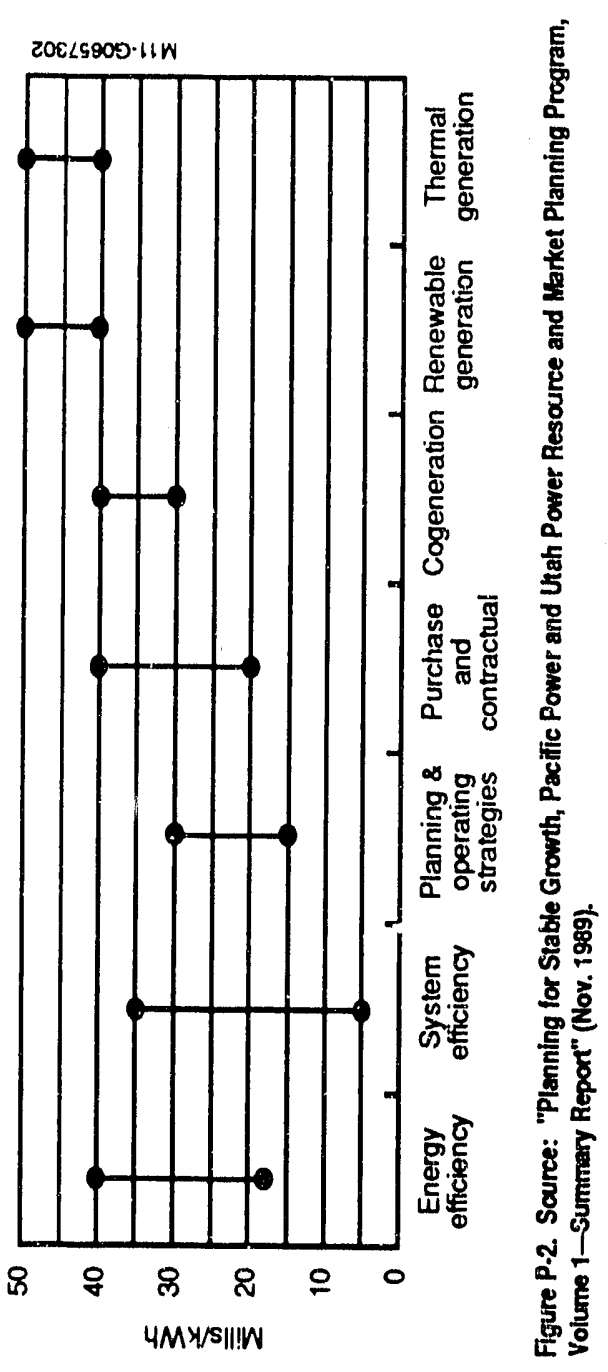

ix 


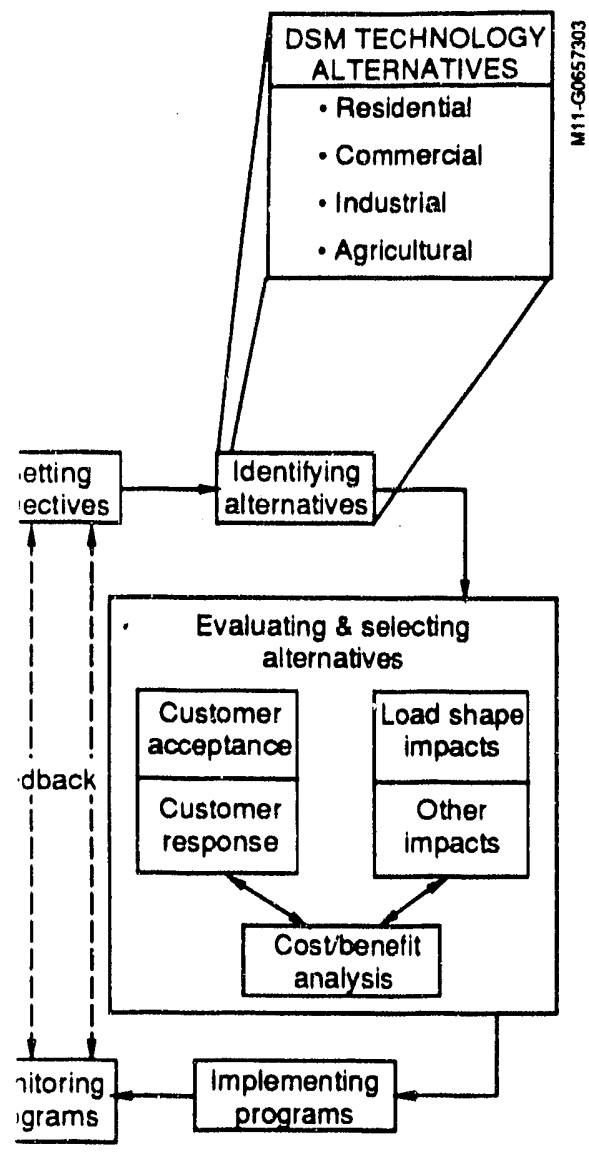

10 P-3. DSU technology alhomativen-postition In the all DSM progrem procens. Sourco: Elcetile Power iench Insttute, "DSM Technology Aitomatives," I EM-5457 (Oct. 1987). practice, this usually means that the technology must provide the same or expanded cost-eflective energy service to the customer while also smoothing out the utility's load curve and delaying the need for additional power plants. This guldebook directly addresses these requirements by estimating the simple payback (to the end user) for energy-efficient end-use technologies and their impacts on the utility's load curve.

A number of additional factors must be considered in technology selection. Primary among these are customer acceptance of different end-use lechnologies, the type of marketing effort required to promote each, and the potential impact on the utility's revenues. These are not addressed in this guidebook.

\section{INTENDED AUDIENCE}

This guidebook is intended to be a quick reference source both for utility tield representatives in their customer interactions and for utility planners in the early slages of developing a DSM program. It is designed to allow a quick screening of commercially available electric end-use technologies with emphasis on the residential, commercial, and agricuthural sectors. Only a limited number of technologies applicable to industrial processing (motors, adjustable-speed drives) are included because industrial customers usually are better iniormed about their energy options, they have more resources and incentive to investigate such options in detail, and the full range of industrial processes is beyond the scope of this guidebook.

Finally, this guidebook is directed primarily at small municipal utilities and rural electric cooperatives within the Western Area Power Administration (Western) service area (see Figure P-4). Large utilities with more abundant resources may find the guidebook uselul as only a starting point. Their technology selection procoss will undoubtedly atso include review of other source documents and detailed system and engineering analyses of the options. 


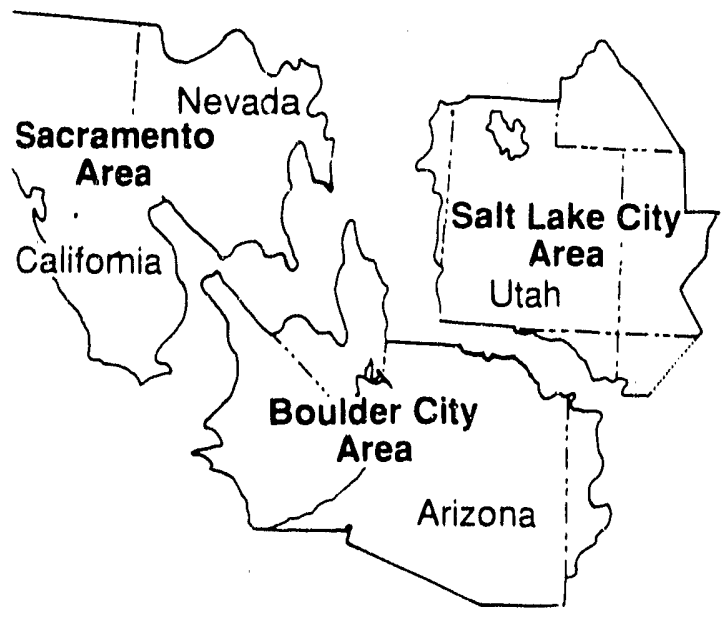

Floure P-4. Wectem Area Power Adminiatration ares mep

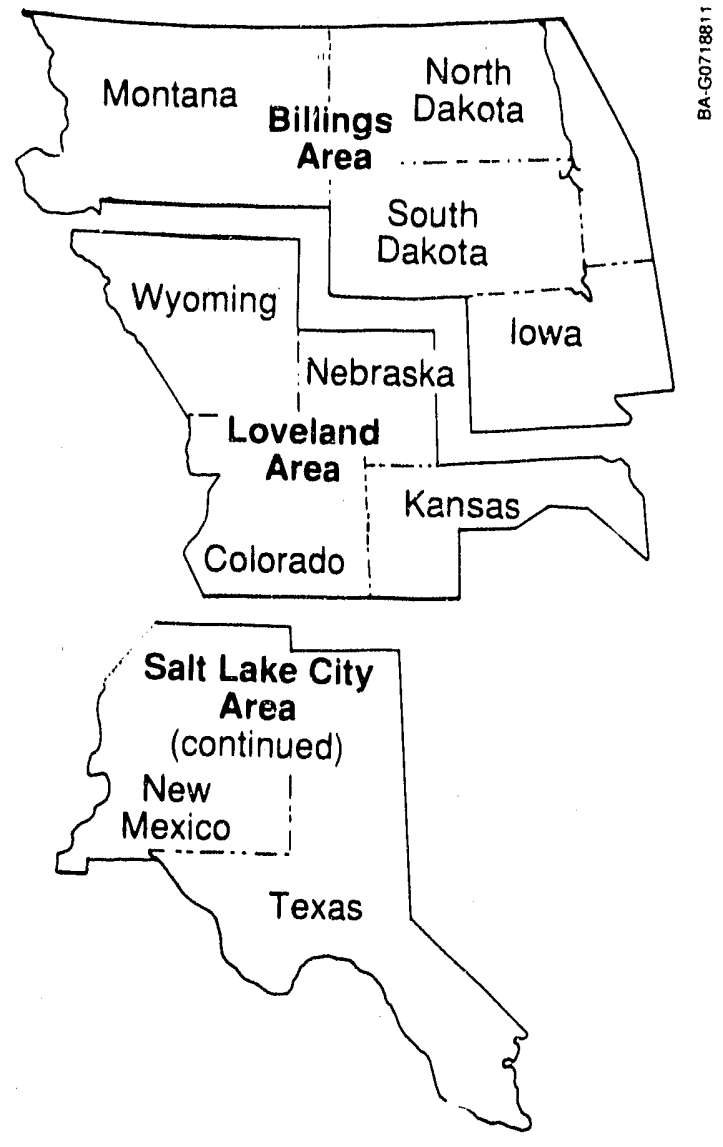

Floure PA (contirued). Wentem Ares Power Administration area map 
METHODOLOGYIDATA

For each technology the guidebook presents a short numbered "lechnology brief"-lext that describes the option, its relevant applications, and its potential impact on the utility's load duration curve. Each briel also includes a summary table (usually not specifically relerred to by number) with quantitative estimates of initial costs, energy savings, and simple payback to the customer. All costs are expressed in 1990 dollars. For most technologies, capital cost and energy savings are estimated for one or more energy-efficient options and a reference caso-usually an electric lechnology.

Where sufficient data exist, payback (to the end user) for the energy' efficient option is also compared to that for the relerence case. Payback is determined by dividing the capital cost (incremental over the relerence case) by the annual dollar savings (relative to the reference case). For simplicity, regional utility variations in electricity prices are ignored; the payback calculations use electricity prices of $\$ 0.08 / \mathrm{kWh}, \$ 0.07 / \mathrm{kWh}$, and $\$ 0.07 / \mathrm{kWh}$ in the residential, commercial, and agricultural sectors, respedively. To estimale payback using actual local electricity prices, multiply the payback by actual electricity price in dollars per kilowatt hour/assumed electricity price in dollars per kilowatt hour. For lechnologies such as replacement windows or insulation in which payback varies based on the climate, a payback range is given or the energy savings and payback are calculated for more than one climate.

Demand charges generally are not included in the payback calculations, because demand rates and possible reductions vary widely by region and utility, and for most of the options demand savings is small. For those technologies that have a large impact on demand (e.9., commercial building cool storage), a range of demand savings is presented and included in the payback calculations.

In almost all cases, the quantitative estimates of costs and energy savings have been laken from existing literature, including documentation of completed utility DSM programs, field studies and experiments, manuiacturers' data, laboratory experiments, and computer simulation and analysis. The sources used varied depending primarily on the availability of data and the complexity of the lechnology. For example, manufacturers' data were used for several cost estimates, but only rarely for pertormance estimates, and then only in conjunction with dala from lield studies or simulations. On the other hand, for more complex technologies such as passive solar home design, the dala were drawn from field s!udies and simulations to caplure all the interactions that occur between building componeris and the local climate.

As might be expected, cost and performance values drawn from different sources are frequently inconsistent. (The reasons for such variations and the resulting uncertainties in the guidebook data are addressed later in this prelace.) To reconcile such inconsistencies, the reports Were first examined in detail and, in many cases, their authors contacted to identify the higherquality studies and/or reasonable causes for the differences. For some lechnologies, we eliminated conflicting sources, elther because the system or climate was not like the one being described in the guidebook, or Decause one analysis was clearly superior. If no clear distinction could be made belween the analyses, the guidebook presents either a range of values or an average value.

Because of the condensed nature of this guidebook and our desire to keep it simple, we have provided only limited reterences for the source materials and computations. The guidebook is not intended to substitute for a delailed analysis, but rather to point the reader toward those lechnologies most likely to benelit both the end user and the utility. For more details, the reader should consult the references (in sections titled "For More Information") at the end of each briel. 
DATA VARIABILTY AND UNCERTAINTY

A problem with guidebooks like this is that the data can at best present oniy a simple overview of each lechnology. Yel hundreds of volumes have been written describing the application of these technologies. Consequently, the cost and performance estimales presented here should be used with a clear understanding of the sources of variability and uncertainly.

Variations in performance occur with climate and with the technology's design and configuration, the system within which it is applied, and the way it is used. Cost varies with the quality or brand of an individual component, the size $\left(\theta . g_{1}\right.$, cost per ton for large commercial air conditioning systems is less than for small unitary systems), the quantity ordered (e.g., cost per lamp for a major commercial retrofit will bo les: :har. the 'retail purchase price of a single lamp), and/or the time of purchase (inflation and technological improvements change costs over time). Generally, the only variation quantified in this guidebook is the range in pertormance with different climatic conditions.

Similarly, there are significant sources of uncertainty in the cost and pertormance data. The uncertainties, which largely result from drawing cost and performance statistics from a number of different sources, inctude

- Lack of complete documentation of the assumptions, data, and methods used in many of the studies

- Lack of slatistically valid generalizations because of small sample sizes (i.e., results in the referenced studies are frequently based on only a fow applications or systems)

- Reference study results based on simulations and limited testing, not field lesting

- The use of multiple studies or sources for the cost and performance values of a single technology.
Where possible; we have avoided such problems t identifying excellent sources. However, as might t expected, we are more confident of some of the resul than others. Thus for many technologies, we has included a rough measure (high, medlum, low) of ol conlidence and the extent of the dala variability ar uncertainty. We expect that future revisions of th guldebcok will provide the opportunity to reduce serr of these uncertainties.

\section{ORGAMZATION AND USE}

\section{OF THE GUIDEBOOK}

The guidebook consists of three pockel-sized volume each introduced by this pretace. The first volur considers end-use technologies for the residenti. sector. The second volume includes technologies for th commercial sector as well as motors and variable-spee drives applicable to the commercial, industrial, an agricultural sectors. The third volume discusses energ: efficient lechnologies for the agricultural sector with a emphasis on the central and western United States (se area map in Figure $P-4$ ).

A number of lechnologies (e.g." energy-efficiel windows) appiy to more than one end-use secto Where applicable, cross references are provided in th brieis. They are also summarized in Table P-1.

Each volume contains two sets of matrices to allow quick screening of the lechnologies. One matri addresses payback values, and the othor lidentifies th most likely impact of each lechnology on the utility loa duration curve (see Figure P-5). A utility planner wh has identified the types of load changes desired and th appropriate end-use sectors can use the matrices I quickly identify candidate technologies. The lext in th briass provides background information. 
Table P-1. Cross-Sector References

\begin{tabular}{|c|c|c|c|}
\hline \multirow[b]{2}{*}{ Tectnology } & \multicolumn{3}{|c|}{ End-Uen Sector / Volume Menaber } \\
\hline & Aouldentive 1 & Conmeretal 2 & Aoritulural 3 \\
\hline Insulation & 1,3 & - & \\
\hline Windows & $4,5,6$ & 1 & \\
\hline Weatherstripping & 7 & - & \\
\hline Duct leaks & 15 & • & \\
\hline Passive solar & 8 & 2 & \\
\hline Heat pumps & 9 & 9 & \\
\hline \multicolumn{4}{|l|}{ Efficient air } \\
\hline conditioners & 13 & 8 & \\
\hline \multicolumn{4}{|l|}{ Energy } \\
\hline management & $\cdot$ & 10 & - \\
\hline \multicolumn{4}{|l|}{ Hoi water } \\
\hline $\begin{array}{l}\text { Solaf } \\
\text { hot water }\end{array}$ & 19 & - & $"$ \\
\hline \multicolumn{4}{|l|}{ Fluorescent } \\
\hline Cooking & 25 & 18 & \\
\hline Swimming pooks & 26 & $\bullet$ & \\
\hline Molors & & $19-28$ & - \\
\hline \multicolumn{4}{|c|}{ 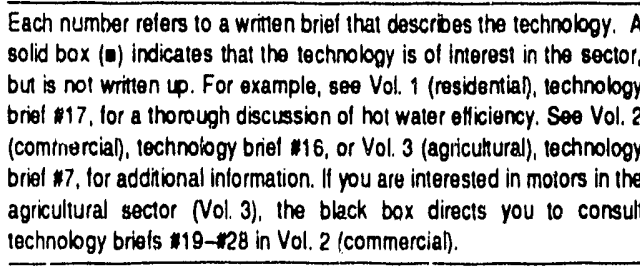 } \\
\hline
\end{tabular}

Load Shifting

Example: Cool storage

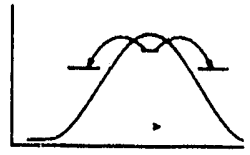

Peak Clipping

Example: Direct control

of air conditioning units

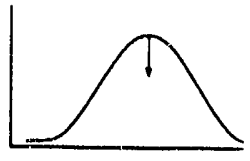

Valley Filling

Example: Thermal

energy storage

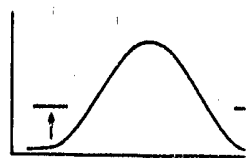

Strategic Load Growth Example: Heat pumps

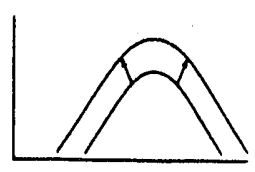

Flexible Load Shape Example: Direct

control of residential water heaters

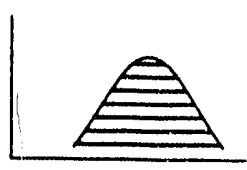

Strategic Conservation

Example:

Weatherization and

efficient appliances

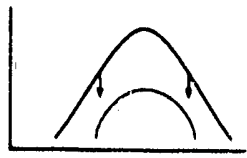

Floure P.5. Typteal load shepe changes rowitting ino eobocted domandaldo attermalyos. Adeptod from Cle W. Gellinge, highllghte of a epeech prosentod to the 1982 Exocuttvo Symponium of EEI Customar Sorvice and Markoting Poreonnol. 
Electricity accounts for $9 \%$ of total United Slates farm energy use. Although this value appears low, it can have a large impact on many small, rural electric utility systems. Of special interest to all utillites is the impact on peak demand, particularly in arld and semi-arid regions, during the summer growing season when irrigation and other agricultural demands are the greatest. For example, Utah Power and Light's irrigation use is only $3 \%$ of annual sales, but comprises $15 \%$ of the systom peak. Agricultural usage in California accounts for about $4 \%$ of sales, but $10 \%$ of peak dernand.

The two largest uses of electrictly in the U.S. agricuttural sector are irrigation pumping (30.8\%) and dairy farming (18.6\%). Together, they represent about $50 \%$ ol electricity use on farms. The remaining uses include liveslock $(27.9 \%)$, nonirrigated larm crops (16.7\%), and poultry (6\%). Figures A-1 and A-2 show the lop five crops (in terms of cash recoipts) in the midwest and the southwest.

Agricultural customers are a highly diverse group. This characteristic makes it hard to generalize energy use patterns or to estimate the effects of load management. Some customers use electricity only a few hours per year and others operate year round. For irrigation, some customers have nearly constant electrical demands between April and October. Others, like dairies, greanhouses, and crop processing operations, have many ditferent electric uses and have highly variable loads. Also, there are important factors influencing agricultural electrical demands that are beyond the customer's control. These include limitations on water supply by an irrigation district, changes in weather conditions, variations in construction and efticiency of equipment, and moisture content of crops. 


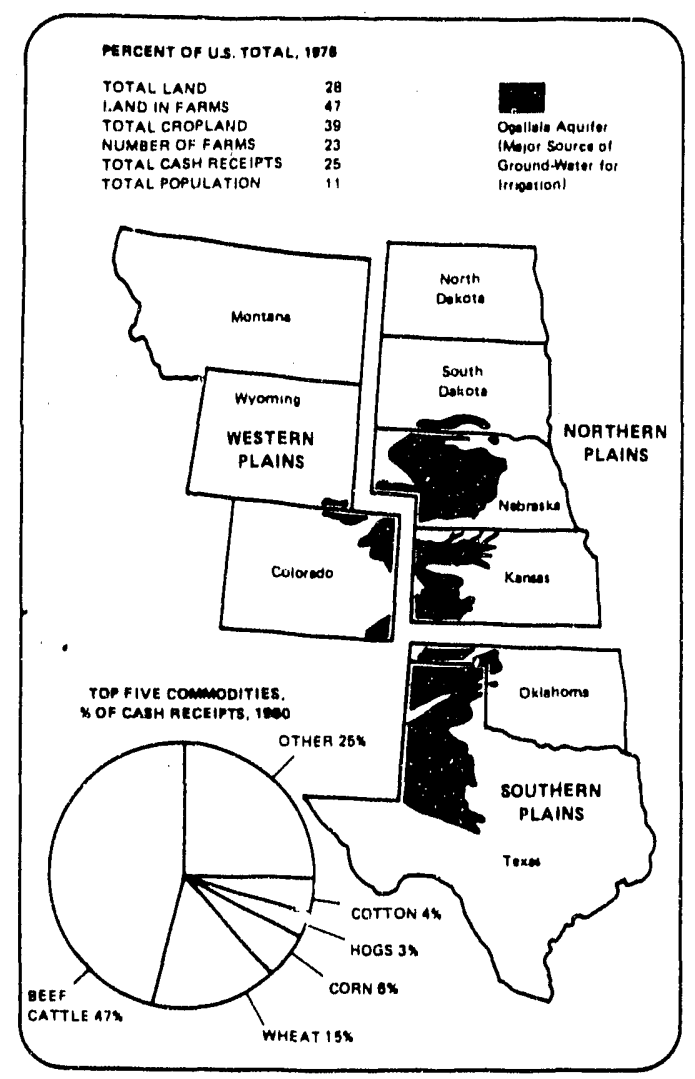

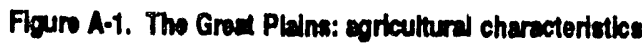

Each electrical farm application is unique and is otten decided largely on non-energy related issues like water consumption, crop yield, and livestock growth. Therelore, costbenefit analyses for agricultural equipment and operations are generally too sile specific

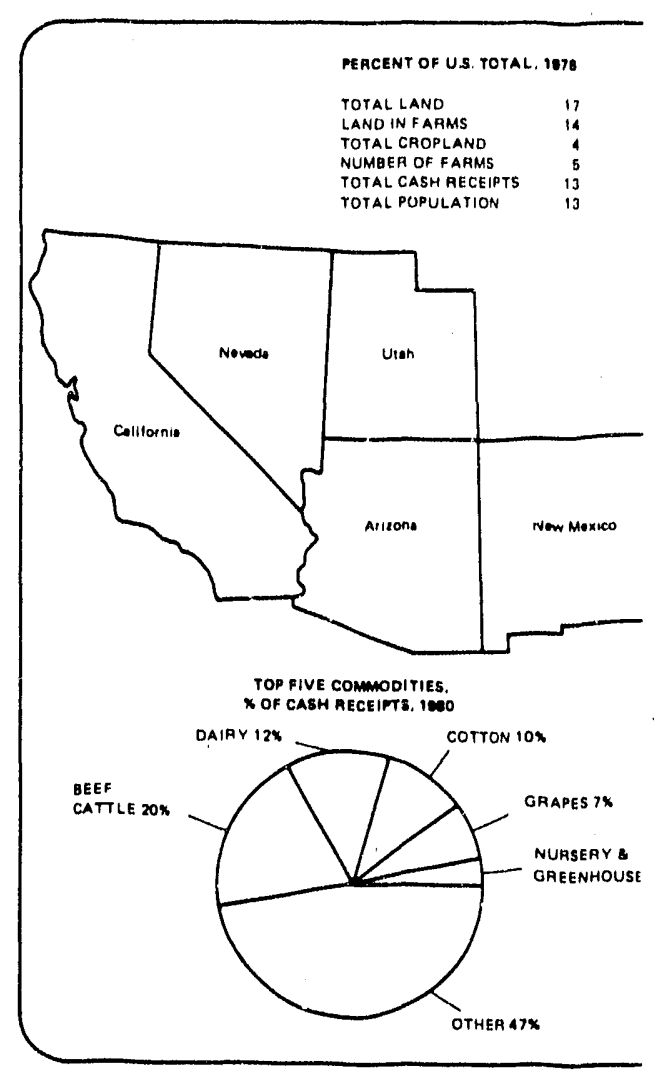

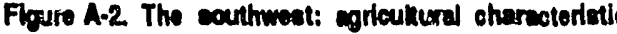
(includes Hawali)

to fit into a quick relerence manual. Instead, in th volume, various equipment and operations a describod and a comparison betwoen allerna technologies is made whenever applicabl. 
Performanca-related information about the equipment or operation is prer anted as electricity use per year per animal or as a unit of oroduction so that the electricity use can be scaled to the energy use of specific operations lound on individual farms.

\section{FOR MORE INFORMATION}

Battelle Press, 1983, Agriculture 2000, A Look at the Future, op. 36, 40.

Each technology discussed in this guidebook contributes to one of six demand-side management (DSM) objectives. The matrix of agricultural ireasures with these DSM objectives is shown in Table , A-1.
Table A-1.

Agriculture: Demand-Side Management Strategies

PC' VF' LS+ SC+ SQ'FL

IRRIGATION
1. Alternativo irrigation systems
2. Irrigation bad management
3. Pumpino plant efliciency
improvement
4. Automation of irrigation

DARY FARM MEASURES

5. Ice-bank vs. directexpansion milk

cooling
Partial in-line coolers or precoolers :
Water heatim
Waste heat recovery
Vacuum pump
Ventilation

MATERIALS HANDUNG

11. Grain conveyarce

12. Feed processing

13. Electric chore vehicles

CROP DRYWG

14. Grain ofying with low.lemperature electric

15. Grain drying with unheated air

16. Controlled aeration lor quality grain

17. Hay drying

\section{UVESTOCK MEASURES}

18. Liectric brooding-poultr

19. Dual fual for livestockbrooding

20. Waterers

21. Earth-lube heal-exchange ventilation systems

22. Controlled ventilation

23. Evaporative cooling systems

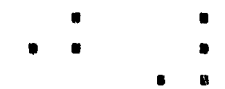

- PC = poak clipping; VF * valley filling; $L S=$ load shifing; $S C$ stralegic conservation; SLG = straiegic load prowh; FLS = floxi load shape

Sources: National Food and Energy Council, 1986, Agricuth Technical Brief Notebook, Columbia, MO. National Food and Ene Council, 1988, Residential Commencial and Agricutural Technolo Columbia, MO. 


\section{IRRIGATION}

- -

Not only is irrigation one of the primary uses of electricity in agriculture, but it represents one of the best opportunities for electric energy conservation and peak demand reduction. The principal measures that can be used to achieve such reductions inciuds the proper selection of an irrigation system and improvements in pumping system efficiency.

A variely of irrigation systems are in use throughout the United States. Energy consumption is one of several important factors in the solection of an irrigation system. In many western arid and semi-arid regions where water supply is linited, the efficiency with which the irrigation system applies water to the roots of the crop is the driving factor. Other factors that trequently play an important role include land slope, soil characteristics, crop typs; fertilizer requirements, and capital and labor costs.

Nonetheless, electric power requirements and costs can be significant in the pumping and distribution of irrigation water. These requirements vary dramatically with the type of system selected. For example, the electric power requirements of a precision application system can be three to four times less than that of a high-pressure center-pivot sprinkler system used in the same field on the same crop. This section of the DSM Pocket Guidebook presents an overviow of the trade-olts that must be considered in terms of costs, application efficiency, and power requirements for the principal irrigation systems. Although the data presented are representa. tive, individual irrigation system costs and portormanco vary significantly from site to site.

(continued) 
Unless the irrigation system is gravity led, waler must be pumped trom the well to the distribution system. Improvements in electric motor efficiency are discussed in Volume 2 ol this guidebook. Concerns that are unique to irrigation pumping efficiency include crop water requirements and irrigation timing, the effect of pumping efficiency of changes in the water table, conversions of an irrigation system to another type, addition or deletion of pumps, triction losses in extended distribution piping, and motor selection. Proper design of an agricultural pumping system should result in a pertormance of about $135 \mathrm{kWh}$ used per acre toot of water per 100 leet of lift. Performance improvements of $25 \%-50 \%$ are possible with proper maintenance.

The following definitions and terms are used in this section: (1) Application efficiency: The ratio of the amount of water stored in the crop roor zone to the amount of water applied to the field. (2) Pumping plant efficiency: The ratio of the water power output (flow times head) to the electrical power input, also called "wire-to-water" efticiency. (3) Conveyance efficiency: The ratio of water delivered 10 a larm or field in comparison to the amount of water diverted from its source. Conveyance elficiency rellects the waler lost to seepage, evaporation, or spilling between the point of diversion and the point of delivery. (4) Pumping plant performance: The energy (in kilowatt hours) required to lift one acre foot of water 100 leel. Measurements that are needed to calculate pertormance are pumping litt in leet, content pumping rale in gallons per minute, and energy (kWh) input during a 24-hour period. Table A-6 shows polential energy savings for efficiency improvements in these units for diflerent litt heights.

$$
\text { Pertormance }=\frac{22,600 \times \mathrm{kWh}}{\text { gpm } \times \text { Liff }}
$$

Terms: gpm is pumping rate in gallons per minute. Liff is pumping lift in feet. $\mathrm{kWh}$ is energy in kilowatt hours. 22,600 is a conversion factor.

\section{DESCRIPTION}

Most irrigation systems fall into three general categories: gravity, sprinkler, and drip systems. Table A-2 show's that in the southwestern United States, gravity systerns consume the highest iraction of electricity used for irrigation. Soe Table A-3 for the application efficiency, pressure, and energy requirements for each of the principal system types. Advantages and disadvantages are discussed below for each general system type.

DRIP A drip irrigation system consists of the pump to draw water from the source, the main line and lateral pipes to supply water to individual plants, and the emitters to control the rate of water flow to each plant. Advantages of drip irrigation include extremely low water usage, automated fertilizer and chemical application, high application efficiency, moderate delivery pressure, and suitability for rocky or steep slopos. Its disadvantages includo high initial costs, clogging, sall accumulation near plant, and polential for water-stressed root development.

GRAVIT FLOW These systems use gravity to transport water at low pressure to the field. With furrow irrigation water is delivered to individual furrows, where as the entire field is flooded in flood irrigation.

FURROW Advantages of furrow irrigatlon include lowpressure transier, low energy usage, and very low delivery pressure requirements. Disadvantages include the requirement for a $2 \%$ natural slope or less, possible need for expensive grading, large quantities of water 
required, high labor costs due to placement of siphon lubes or piping, and very low application efticiency.

FLOOD Advantages include low-pressure transfer, low energy usage, and very low delivery pressure requirements. Disadvantages include its suitability for level fields only, the possible need for expensive grading, the need lor large quantities of water, imprecise application, and low application elficiency.

SURGE SUrge irrigation is the intermittent application of water to furpows. The flow of water is allernated between two sets of furrows on either side of a surge valve installed in a gated pipeline. When the gales are opened, water is delivered in pulses or surges to each set of gated pipe on either side of the valve.

The surge method saves water. Its advantages include last advance and unitorm distribution of water down the furrow, smoothing of soil as the water infiltrates, the lack of deep percolation al the turrow head, and low delivery pressure. Disadvantages inctude the possible need lor additional pipe and expensive grading and the cost of surge valves.

SPRINKLER Sprinkler irrigation consists of systems that transter water to the crop through pressurized piping and sprinkler heads to spray water over crops. CENTER PNOT Suttable lor large acreijes, the center-pivot system has several advantages. Water is distributed properly and land grading is nol required (the system can operale over rolling land). It is easily automated and little labor is required; application elficiency is high compared to flood or furrow irrigation. Its disadvantages include some waler loss from ovaporation, high energy requirements for pumping and lateral movement, and the need for high delivery pressure (although lower-pressure systems are available).

LINEAR MOVE In this system, suitable for rectangular fields, water is distrbuted properly and no land grading is required. Application efficiency is high compared to "zod or furrow irrigation. Its disadvantages include some water loss from evaporation, high energy requirements for pumping and lateral movement, and the need ior high delivery pressuie (although adaptation to low-pressure nozzles is easily accomplished).

TRAVELING GUY In this system water is properly distributed, land grading is unnecessary, and labor requirements are low. However, water is los! to evaporation, energy requirements are high for pumping and cart movement, application elficiency is low, and very high delivery pressure is required. 


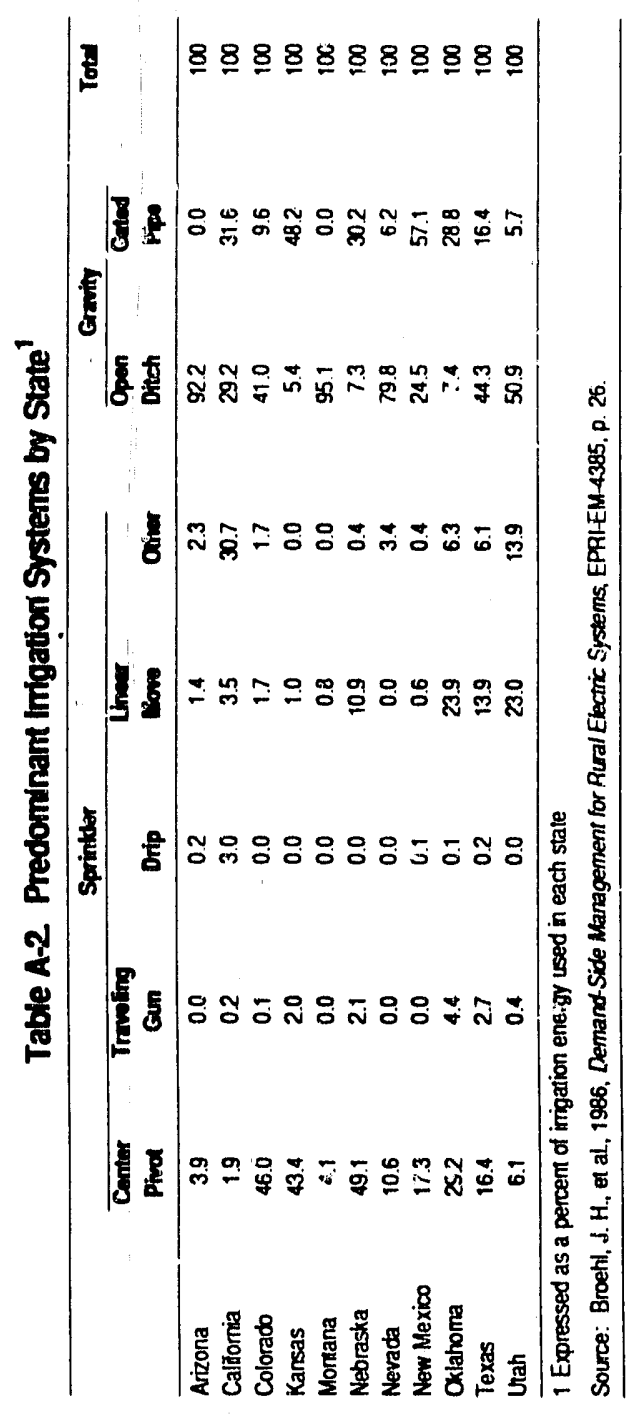

12

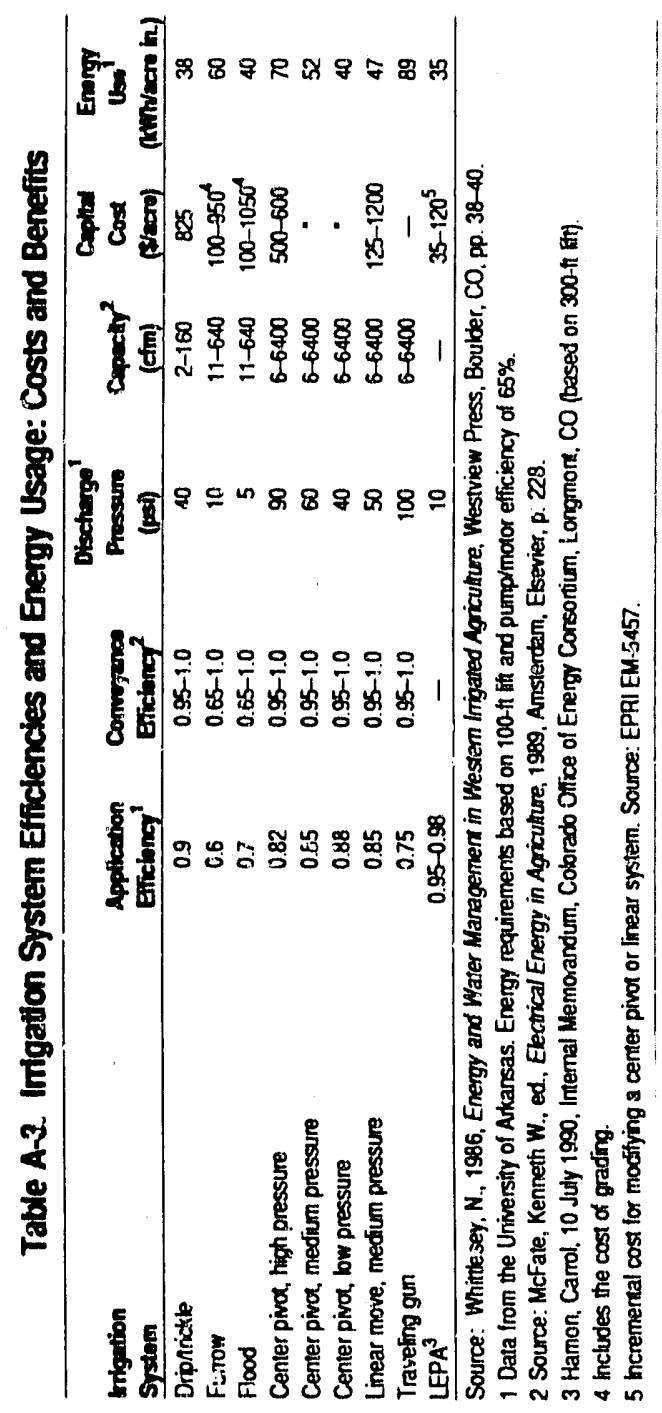




\section{IRRIGATION LOAD MANAGEMENT}

\section{DESCRIPTION}

Irrigation load management controls can be used to reduce peak demands in both arid and semi-arid regions of the couniry. The utility oflers irrigators one or more control options al reduced rates. The irrigator selects control options based on crop needs, cost savings, irrigation system llexibility and capacity, and management abilities. Savings resulting from the reduction in peak demand are shared by the irrigator and the utility. Irrigators reduce operating costs, and utilities pay for the load management control system through savings in demand costs. Care must be taken to avoid crop losses, a possible result of untimely irrigation. For more information on load management, see technical briel \#10 on energy management in Volume 2 of this guidebook.

\section{APPLCABILTY}

CLIMATE Semtarid to arid areas benelit most. The greatest potential for inigation load control and utility electrical demand reductions depends upon irrigation systems that have adequate water supplies, soils that have minimum water holding capactios of 1.5 inches per foot of soll depth, and automated irrigation systems. DEMAND MANAGEMENT OBJECTIVES Strategic conservation, peak clipping

\section{COSTS AND BENEFTS}

Costs for individual controllers are about the same as lor controllers used with water heaters and air condltioners; however, installation costs are highe Although lower units are neoded to control lar! demands, more transmission equipment is needed send signals to the controllers than is needed by wat healers or air conditioners.

\section{FOR MORE INFORMATION}

National Food and Energy Council, 1986, Agricultu Technical Briel Notebook, Columbia, MO, p. AT-107 
AGRICULTURAL BRIEF 3

PUMPING PLANT EFFICIENCY IMPROVEMENT

\section{DESCRIPTION}

Although the maximum theoretical efficiency for a pumping plant is about $75 \%$, results of most pumping lests show that the average pumping plant efficiency lalls between $50 \%$ and $60 \%$. To ensure maximum elficiency, all three principal components of the irrigation pumping plant-motor, drive shaft, and pump assembly-must be designed to tit the system and must be kept in good repair. Figure A-3 shows the sources of pumping plant losses tor a well tuned $(71.5 \%$ elticient) plant.

Regardless of the distribution system, conveyance efficiency, and pressure requirements of various irrigation systems, it is still necessary to pump water to the distribution system. Much of this water is pumped from wells, especially in the midwest where water tables have declined. Table A.4 shows the range of water table depths for midwestern and southwestern states.

If you know the pumping lift and distribution system pressure requirements, you can use Table A.5 to estimate the electrical energy required per acre loot of water.

Many electric utilities offer pumping plant efficiency lesting for their customers. A simple test that lakes about an hour can deterinine water discharge rate (gpm), discharge pressure (psi), power requirements (hp), energy consumption (kWh), and water pumping level. Then, an estimate of potential savings can be made.

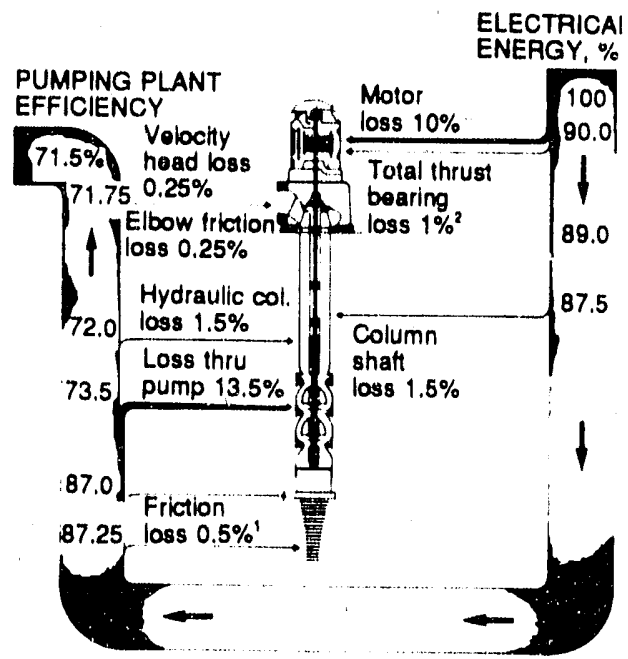

Flguro A-3. Typleal targo pumping plant syatem offlelency losece-irom deep well withine Input to distribution compononts. Countesy P.G. \& E.

Table A-4.

Pump Lft Ranges for Major Groundwater-Irigated States in the West

\begin{tabular}{lc}
\hline \multicolumn{1}{c}{ stute } & $\begin{array}{c}\text { Pumping Lift } \\
\text { (ficot) }\end{array}$ \\
\hline Arizons & $75-535$ \\
Calitornia & $75-300$ \\
Coborado & $175-270$ \\
Kansas & $175-250$ \\
Nebraska & $25-250$ \\
Now Mexico & $75-225$ \\
Oklahoma & $200-275$ \\
Texas & $75-225$ \\
\hline
\end{tabular}

Source: Whittlesey, Norman K., ed., 1986, Energy and Management Westem Imigated Agriculture, Boulder, CO: Westview Press, p. 10? 
Table A-5. Pumping Energy Requirements for Different Lift's and Dellvery Pressures

Enargy Roquiroments (kWh/acro toot)

\begin{tabular}{|c|c|c|c|}
\hline \multirow{3}{*}{$\begin{array}{l}\text { LIft } \\
\text { (toot) }\end{array}$} & \multicolumn{3}{|c|}{ Enorgy Requlrements (kWh/acro foot) } \\
\hline & & Iary Pres & \\
\hline & $40 \mathrm{ps} /$ & $60 \mathrm{ps} 1$ & $80 \mathrm{ps}$ \\
\hline 50 & 260 & 350 & 440 \\
\hline 100 & 350 & 440 & 525 \\
\hline 200 & 525 & 610 & 700 \\
\hline 300 & 700 & 790 & 875 \\
\hline 400 & 875 & 960 & 1050 \\
\hline 500 & 1050 & 1140 & 1230 \\
\hline
\end{tabular}

APPLCABILTY

All crop irrigation systems.

- DEMAND MANAGEMENT OBJECTIVES Strategic conservation, strategic load growth

\section{COSTS AND BENEFTIS}

Table A-6 provides a quick estimate ol potential savings given present pumping efficiency and present annual acre-inch requirements assuming a final efficiency of $65 \%$. To use the table find your present pump elficiency in the top row and select the entry for the given lift. Now apply your $\$ / k W h$ rale and acre-inch requirements to the figures 10 determine yearly savings. The cost for efficiency testing of equipment ranges from $\$ 2,000$ to $\$ 4,000$ and is about $\$ 200$ per test.

Savings calculation: Present elficiency (tested) $40 \%$; final system efficiency (assumed) $65 \%$; lift $200 \mathrm{Ht} \$ \$ / \mathrm{kWh}$ $\$ 0.04$; annual water requirement 1500 acre-th. From Table A-6; Savings $=16.4 \mathrm{kWh} / \mathrm{acr} \theta-\mathrm{in}$; annual savings $=(16.4)(0.04)(1500 \times 12)=\$ 11,800$.

\section{FOR MORE INFORAMATION}

National Food and Energy Council, 1986, Agricultural Technical Briof Notebook, Columbia, MO, p. AT-\{08.

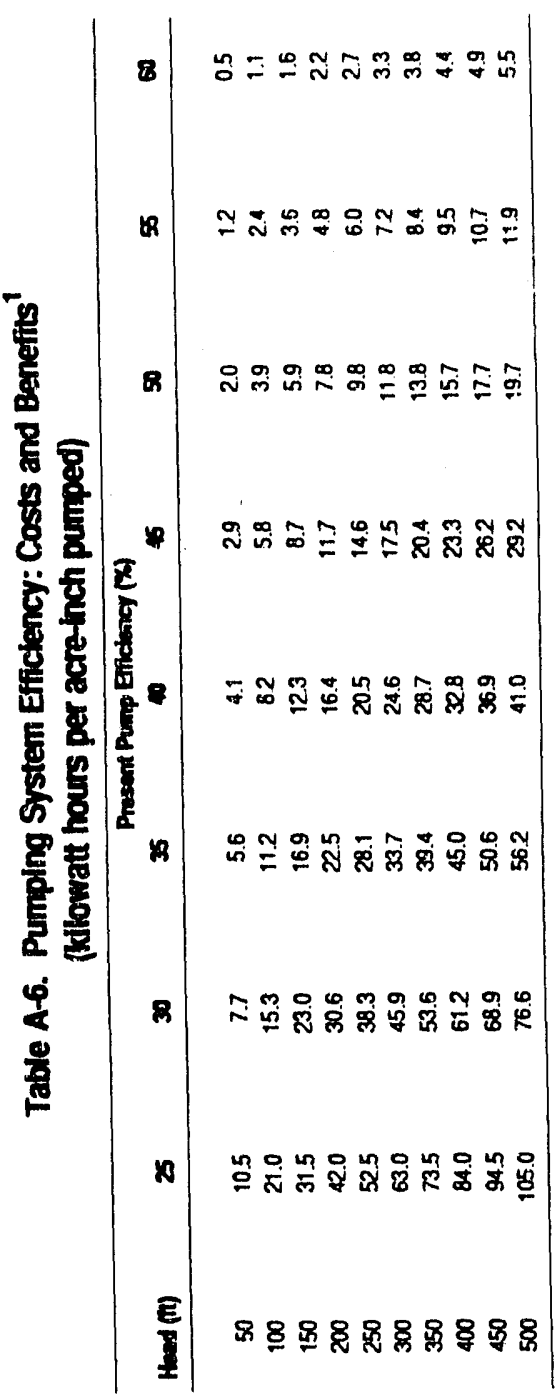

19 
per-acte savings for low (10 in./season) and hig AUTOMATION OF IRRIGATION

\section{DESCRIPTION}

This brief covers computerized irrigation control and scheduling. In computer irrigation control, an on-larm computer remotely controls irrigation pumps and sprinkler systems. Software permils four major management functions. Monitoring allows the irrigator to detect mechanical failures quickly. Remote onntrol allows for quick changes to the system in respo ise to manage ment neөds. Irrigation scheduling responds to weather conditions. Load interruption automatically allows for peak shitting. In some areas, water and energy savings amount $1030 \%$.

Compared to simpler timing devices, computer control allows for an interruption sequence based on the amount of water that is needed and available. Furthermore, monitoring protects against yield loss caused by undetected breakdown. For the utility, a predetermined amount ol load can be shed. If you know your seasonal waler usage (inches) and irrigated area (acres), you can use the last column in Table A.3 to estimate annual energy requirements.

In computerized scheduling, real-time weather data are used to estimate evapotranspiration (crop water use) and to forecast the next time for irrigation. Water budgets are calculated by adding rainfall and irrigation, then sublracting evapotranspiration, surface runoff, and drainage below the root zone. Forecasts for the water budget are based on climale averages for the previous fow days. Weather data are obtained from state networks or from on-site weather stations.

Savings of waler and energy is between $10 \%$ and $30 \%$. Crop production is usually increased by more timely irrigations. The cost of scheduling is often offset by a decrease in operating costs and an increase in crop sales. Table A-7 shows some representative annual systems assuming $10 \%$ and $30 \%$ savings from th control system. These figures do not represent ith corresponding savings in waler.

APPLICABILTYY

CLIMATE Weather data and soil moisture content mus be available.

DEMAND MANAGEMENT OBJECTIVES Strategi conservalion, peak clipping

\section{COSTS AND BENEFTIS}

The cost of a radiolelemetry system for computer cor trol varies depending on the number of units served b one computer, the sprinkler interfacing required, an customization of sensors and software. A system ser ing between 10 and 20 sprinklers costs $\$ 3000-\$ 400$ per control point. Assuming 100 acres per point, pa) backs range trom 8 years for $10 \%$ savings in low wate usage applications to less than 6 months for $30 \%$ sal

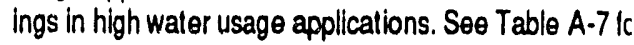
more information.

The cost for soltware for scheduling irrigation varie widely between $\$ 500$ and $\$ 5,000$ per unit. Some gor ernment agencies provide such soltware tree. On-sit weather stations cost about $\$ 2,500$; however, informe fion from local weather networks usually can b oblained inexpensively. Paybacks are similar to thos for irrigation control strategies.

FOR MORE INFORMATION

National Food and Energy Council, 1986, Agricultur: Technical Briets Notebook, Columbia, MO, p. AT-112 


\section{DAIRY FARM MEASURES} - :

The three major electrical energy uses on dain are milk cooling, waler heating, and vacuum pl In addition to these uses ventilation, lightins processing, and other electrical equipment signi affect electricity use and demand.

Electrical energy use per cow or per unit of $m$ duced varies with dairy larm size, climate con and management practices. Decisions on wha and when dairy farm operalions take place can influence electricity use and the cost of producl 
ICE-BANK VS. DIRECTEXPANSION MILK COOLING

\section{DESCRIPTION}

Most milk is cooled in bulk coolers. Direct-expansion milk coolers and ico-bank milk coolers are the two most commonly used bulk coolers in the Uniled States. Cooling in cans with mechanical retrigeration is no longer common. Regardless of the method used to cool milk, all methods must meot FDA standards set for cooling requirements. Milk must be cooled to $45^{\circ} \mathrm{F}$ or less within two hours after milking. The blend temiperature in the bulk tank after the first and subsequent milkings must not excoed $50^{\circ} \mathrm{F}$. Maintaining the blend temperature usuailly requires more retrigeration than the initial cooling.

The most common method used to cool milk is direct expansion. This method uses a slorage tank with a reirigerated jacket. In the jackels are evaporator plates that contain a freon relrigerant thal expands and ab. sorbs heat from milk. The milk is in direct contact with the stainless steol tank liner and must be stirred in the tank so that it makes contact with the refrigeraled surtace. Evaporator plates and condensing units must be sized carefully to meel industry si.zndards. A 3-hp condensing unit with a directexpansion system will cool about 600 pounds of milk per hour to $45^{\circ} \mathrm{F}$. Large dairies usually require two large condensing units with a large bulk tank and extensive evaporator surlace.

Another means of cooling milk is through the use of an ice bank. An lco-bank milk cooling system uses ice that is Irozen during the utility's oft-peak hours. Chilled water is circulated through the ice to an in-line heat exchanger that cools the milk $1038^{\circ} \mathrm{F}$ as it is being transterred to the bulk storage tank. No further cooling is required in the storage tank. lco-bank systems are most applicable on large dairy larms where milk is produced al hig rales over several hours twice a day. In an ice-ban system, blend ternperatures are not a problem and ove all milk quality is improved, because all milk is intrc duced into the storage tank al the required temperatur and little agitation is required. Peak electrical loads ca be reduced because condensing unils can be sized I produce ice during oll-peak hours. Overall energy us is about $25 \%$ grealer than direcl expansion because । standby losses in the ice bank and storage tank as We as colder mllk temperatures (around $38^{\circ} \mathrm{F}$ rather tha $45^{\circ} \mathrm{F}$.

\section{APPLICABILTTY}

Direct expansion is most applicable for small to mec um-sized dalies with low to moderate (up to $1500 \mathrm{lb} / \mathrm{l}$ milk.loading rales. Milk will be cooled with up to $25^{\circ}$ less electricity than when lco-bank systems are use For large dairies, however, condenser horsepuwer $\mathrm{me}$ be high, which could add a large electrical load to tt syslem peak, creating high year-round demand charge Also, larger tanks have a smaller condenser surtac area-10-volume ratio requiring excessive stirring, whic can lower the quality of the milk.

Dairles with high milk-loiading rates coupled with elect demand meters or time-ol-day meters can beneit si nilicanily from ke-bank oystems. The peak load will t less and milk cooling anis quallty problems are reduce DEMAND MANAGENENT OBJECTIVES (for an " bank): peak clipping, load shilting

\section{FOR MORE INFORMATION}

National Food and Energy Council, 1986, Agricultu, Technical Brief Noiebook, Columbla, MO, p. AT-116 
Table A-8. Ice-Bank vs. Dlract-Expansion Millk Cooling: Costs and Benefits

\begin{tabular}{|c|c|c|}
\hline Equpment or Load & 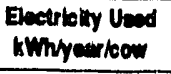 & Cornments \\
\hline $\begin{array}{l}\text { Direcl-expansion buk } \\
\text { tank with precooler }\end{array}$ & 95 & $\begin{array}{l}\text { Mid-8ized dairiog } \\
(500-1500 \mathrm{lb} / \mathrm{h})\end{array}$ \\
\hline $\begin{array}{l}\text { Diroct-dxpansion buk } \\
\text { lank without precooler }\end{array}$ & 143 & $\begin{array}{l}\text { Mid-sized dairlos } \\
(500-1500 \mathrm{lb} / \mathrm{h})\end{array}$ \\
\hline \multicolumn{3}{|l|}{ Direct-expansion buk tank } \\
\hline $\begin{array}{l}\text { whit condenser } \\
\text { heal exchanger }\end{array}$ & $\begin{array}{c}82 \\
112\end{array}$ & $\begin{array}{l}550 \text {-cow herd } \\
140 \mathrm{cw} \text { orear/cow }\end{array}$ \\
\hline$\cdot$ & & 6.36 vyoar per cow \\
\hline $\begin{array}{l}\text { Direct-expansion } \\
\text { buk tank without } \\
\text { condenser heat exchanger }\end{array}$ & $\begin{array}{c}154 \\
147-163 \\
151\end{array}$ & $\begin{array}{l}\text { Alemale day plckup } \\
\text { 60-1L0-cow helds } \\
\text { 140-cow herd }\end{array}$ \\
\hline $\begin{array}{l}\text { Ice.bark cooler } \\
\text { without condenser }\end{array}$ & $182-278$ & $\begin{array}{l}140 \text { cwivear } \\
6.36 \text { Vyear/cow }\end{array}$ \\
\hline heat exchanger & 142 & 550-cow herd \\
\hline Can cooler & 160 & Small hard \\
\hline \multicolumn{3}{|c|}{ 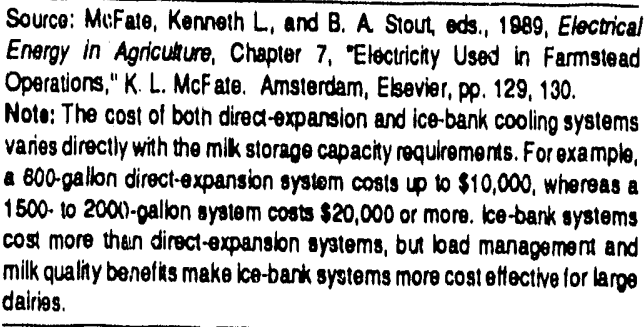 } \\
\hline
\end{tabular}

PARTIAL IN-LINE COOLERS OR PRECOOLERS

\section{DESCRIPTION}

Partial in-line coolers are used to precool millk beic enters the bulk tank by transierring the milk's hei well water. For example, this process will cool gallon of milk $1070^{\circ} \mathrm{F}$ from $90^{\circ} \mathrm{F}$ while raising gallons of well water from $55^{\circ} \mathrm{F}$ to $65^{\circ} \mathrm{F}$. Although s electrical energy is needed to run the water circuli pump, it is considerably less than that require operate the compressor molor to provide equivi cooling capacity. However, energy savings alone wi pay for a partlal in-line cooler except in large dai The energy savings combined with increased millk ing capacity may justify partial cooling, especially i spent temfored water can be used for some addit: purpose such as cleanup, prepping cows, flus floors, or animal consumption. The potentlal ar energy sevings for partial in-line cooling is show Table A-9. Note that the savings figures do not ace lor use of the lempered waler for some other purf

\section{APPLICABILITY}

Large dairies; retrofits to expand present system ci ity; dairies with unconstrained well water supply need for warm nonpotable water.

DEMAND MANAGEMENT OBJECTNE Stralegic servation, poak clipping 


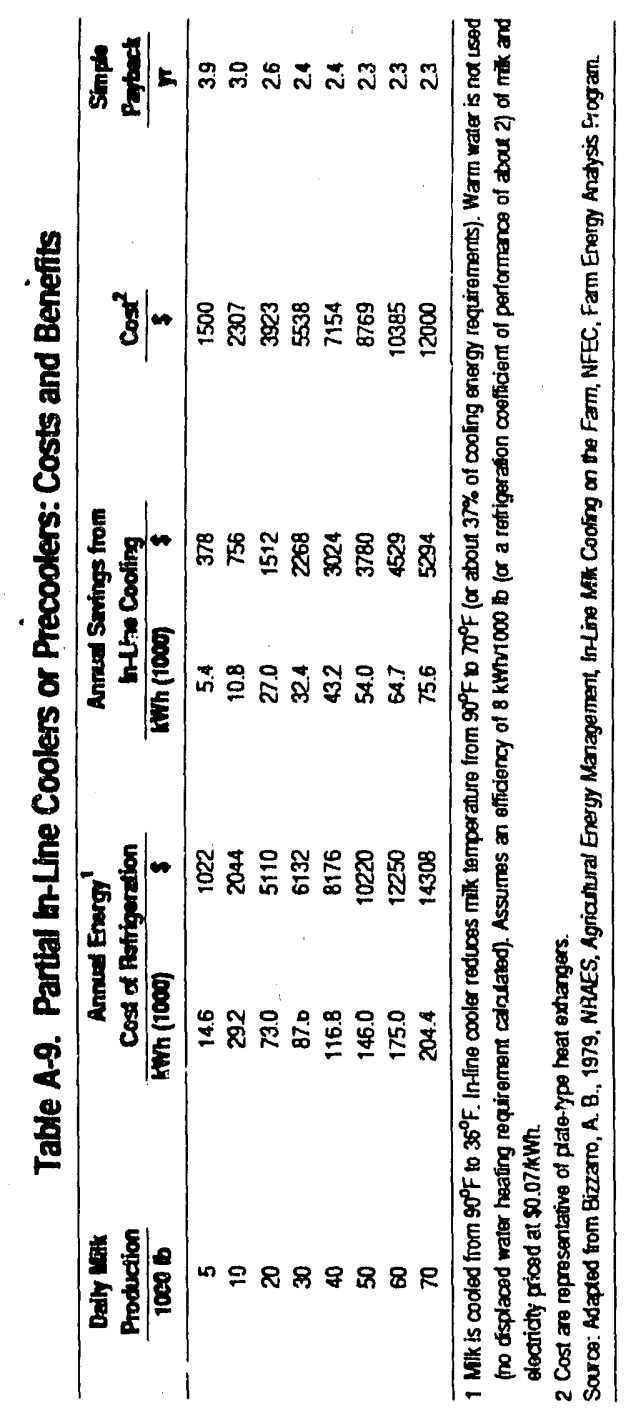

28
WATER HEATING

\section{DESCRIPTION}

Water heating accounts for up to $40 \%$ of the electri energy consumed on a dairy farm. The two pincil uses of hot water on a dairy tarm require dillert temperatures. Washing of millking equipment require! temperature of $160^{\circ} \mathrm{F}$, and washing cows' udders beik milking requires water with a lemperature of $100^{\circ}$ Other fypical uses for warm water is for consumption the cows, which increases their intake and productic and for filling flush tanks for parlor washing.

There are twe major types of milking equipment. Pif line systems, generally employed for herds of more th 40 cows, require a larger quantity of water for washi than a non-pipeline system. The voluirie of water us in a pipeline system can be measured and will ren. relatively constant over a period of time. Typicali: pipeline system requires 2.4 gallons per day per row water at $160^{\circ} \mathrm{F}$.

Non-pipeline milking systems, sometimes ca."ed tuck systems, use less hot water for sanitation than pipel:' milking systems. Although the amount of hater used difficult ic measure, when it is delermine" the amoii remains relatively constant for each milkiı. $t$.

Farm water heating energy and demand requir - ien can be reduced in four ways:

- Waste heat recovery

- Insulation

- Efficiency improvements

- Load management.

The reader should consult the section on residenti water heating (in Volume 1 of this guidebook) 1 possible insulation and efficiency improvements (e.f heat pumps). These are essentially the same for all $h$ water requirements. The additional requirements $f$. 
high temperatures and long pipo runs found in dairy larms make tank and pipe insulation even more cosi effective. Load management for dairy larm waler heating is facilitated by the regularity with which hot water is required for udder washing and the cleaning of milking equipment. Demand control options are discussed in Volume \%, briel $\$ 20$ (water heating cycling control) and in Volume 2, brief \#10 jenergy manago ment systems).

Energy for water heating on dairy farms averages around $160 \mathrm{kWh}$ per cow annually. This usage can be reduced by waste heat recovery methods described in the next briet.

\section{APPLCABILTTY}

. DEMAND MANAGEMENT OBJECTNE Strategic conservation

FOR MORE INFORMATION

MCFate, Kenneth, L., and B. A. Stout, eds., 1989, Electrical Energy in Agriculture, Chapter 7, "Electricity Used in Farmstead Operations," K. L. McFate. Amsterdam, Elsevier, p. 130.
AGRICULTURAL BRIEF B

WASTE HEAT RECOVERY

\section{INTRODUCTION}

There are several sources of heal from a retrigeration unit. One is the heat removed from the milk $10 \mathrm{cool}$ it from $90^{\circ} \mathrm{F}$ to $40^{\circ} \mathrm{F}$. Another is the wasto heal from the compressor and motor. Most ol the heat is contained in hol gas that comes from the compiessor. Typically, condenser coils and lans are used fo reject this heat to the atmosphere.

Heat from the relrigeration system can be recovered in the form of hot water by using either an add-on heat exchanger or a heat exchanger bult into the condenser. Depending on the type of heat exchanger that is usid, a $75 \%$ reduction in water heating energy requirements can be realized.

ADD-ONHEAT EXCHANGERS (DESUPERHEATERS) Add-on heal exchangers are installed in series, along with a water slorage tank and a crculating pump, between the discharge side of the cooling system compressor and the existing air-coled condenser (Figure A-4). Because these units capture only retrigerant superheat, only $15 \%-50 \%$ of the available heat is recovered. Some of the heat is lost through the condenser. Therefore, the air-cooled condenser must remain in the system when the add-on heat exchanger is installed. Water temperatures of $90^{\circ} \mathrm{F}-110^{\circ} \mathrm{F}$ result, with a reduction in water heating cosis of $30 \%-40 \%$, Add-on heal exchangers cannot capture as much of the available heat as complete condensing heat exchangers, but they are much less expensive. 


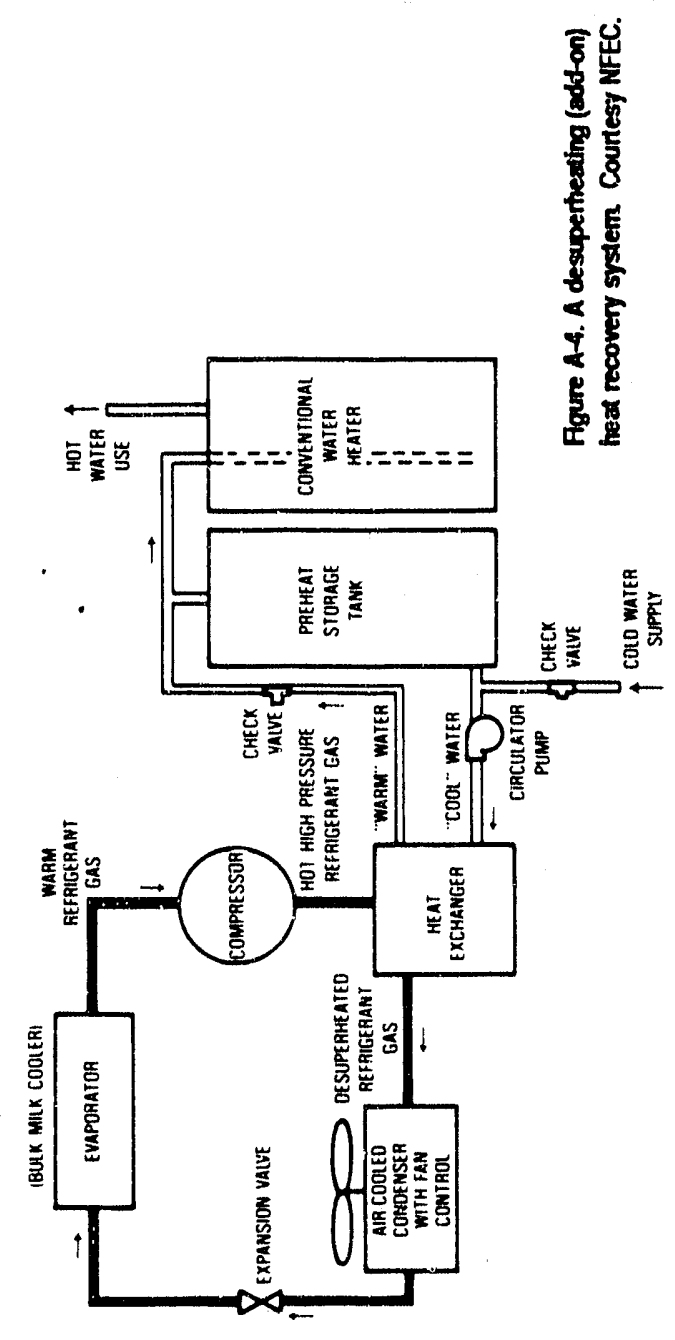

COMPLETE CONDENSING HEAT EXCHANGERS

The complele condensing hoat exchanger is a special water-coled condenser unit instead of the typical aircooled condenser (Figure A-5). Depending on thra heattransfer efticiency and the rate at which hot water is removed, condensing heat exchangers are capable of heating waler up $10180^{\circ} \mathrm{F}$, because nearly all refrigera. tion heal as well as heal producod by the compressor and motor is transferred. However, typical complete condensing heat exchangers produce water temperalures between $120^{\circ} \mathrm{F}$ and $150^{\circ} \mathrm{F}$. Water heating costs are reduced by $60 \%-85 \%$. Complele condensing units are added when a water heating system is installed or replaced. Proper sizing of the storage tank is important to ensure a constant supply of cold water to the condenser. If the inlet water temperature to the condenser gels too high, refrigeration efficiency is decreased. Some units dump excess heated water when the tnm. perature rises too high; other systems have a back-up condenser coil and tan.

\section{APPLCABILTTY}

New or retroilt dainy water heaters.

DEMAND MANAGEMENT OBJECTIVES Slrategic conservation, peak clipping

\section{COSTS AND BENEFTIS}

See Table A-10 for the annual savings possible with a complete condensing heat exchanger that recovers $90 \%$ of the heat from the relrigerant. Add-on heat exchangers cost between $\$ 1000$ and $\$ 1600$. Complete condensing units are much more expensive, because refrigeration compressors are frequently included. 


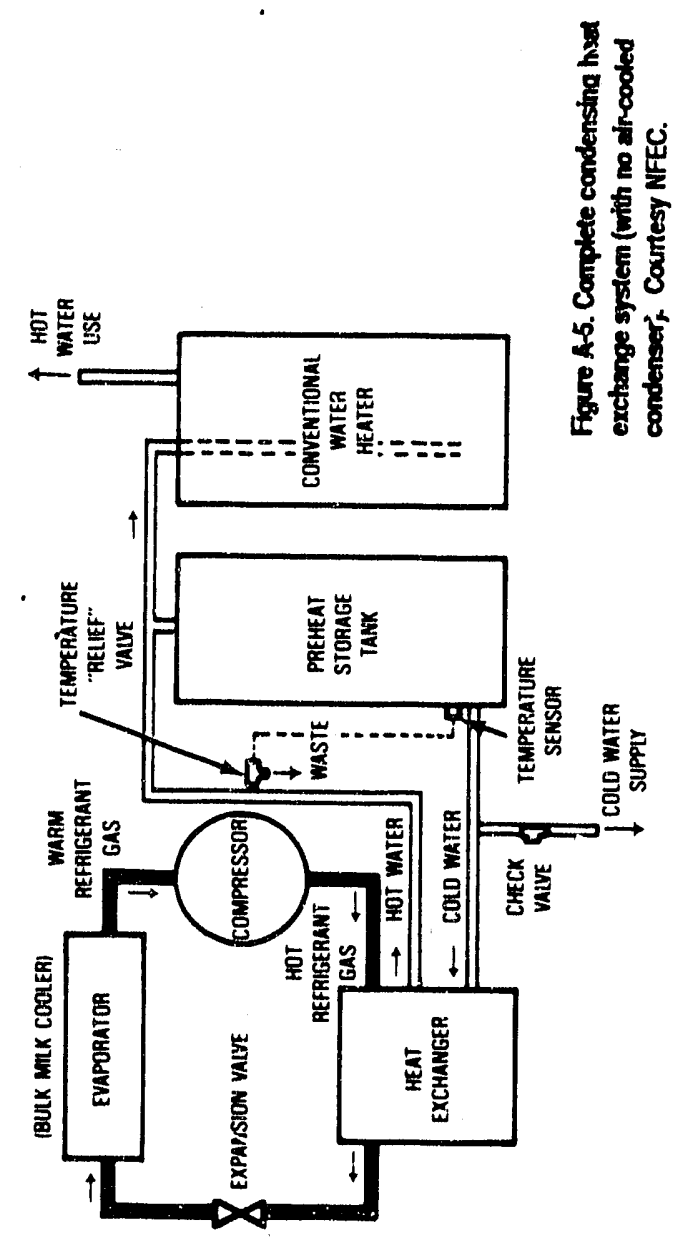

Table A-10.

Waste Heat Recovery: Costs and Benefits ${ }^{1}$

\begin{tabular}{|c|c|c|c|c|}
\hline $\begin{array}{l}\text { Dally Mil } \\
\text { Production } \\
\text { (1000 Ibs) }\end{array}$ & $\begin{array}{l}\text { 140\% F Witor } \\
\text { Produced } \\
\text { Delly } \\
\text { (geilons) }\end{array}$ & 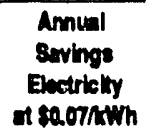 & $\begin{array}{c}\text { Cost of } \\
\text { Syetem } \\
\text { (i) }\end{array}$ & $\begin{array}{c}\text { Paybeck } \\
\text { (yi) }\end{array}$ \\
\hline 5 & 432 & 1217 & 2000 & 1.6 \\
\hline 10 & 864 & 2433 & 2846 & 1.2 \\
\hline 20 & 1728 & 4886 & 4538 & 0.9 \\
\hline 30 & 2592 & 7290 & 6231 & 0.9 \\
\hline 40 & 3456 & 9732 & 7923 & 0.8 \\
\hline 50 & 4331 & 12165 & 9615 & 0.8 \\
\hline 60 & 5188 & 14598 & 11308 & 0.8 \\
\hline 70 & 6064 & 17031 & 13000 & 0.8 \\
\hline
\end{tabular}

1 Based on complate condensing exchancer recovering $90 \%$ of heal trom refrigeram gases. Savings based on using $50 \%$ of the hot water produced. This is possble if water is used lor flush tanks and cow watering. In genaral, complete condensing units produce hisere hot water than can be used. Annual displacod waler heating based or $107^{\circ} \mathrm{F}$ temperature rise.

Source: Adapled Irom Poterson, R., and R. Koolson, 1979, "Dain Farm Heal Exchangers for Healing Water," Northeast Regional Agricultural Enginoering Sorvice, p. 3. 


\section{VACUUM PUMPS}

\section{DESCRIPTION}

The average vacuum pumping requirement on a dairy larm is about $150 \mathrm{kWh} / \mathrm{cow} / \mathrm{year}$, which puts it on par with milk cooling and water heating energy requirements. Because vacuum pumps on must dairy tarms are operated many hours each day, the cost of operating a pump with a motor that is larger than necessary can be cosily. Although motors for vacuum pump systems vary from about $11010 \mathrm{~kW}$, the motors should be no larger than necessary. Industry guidelines for a pipeline milking system require about $1.2 \mathrm{~kW}$ of electric motor capacity for each milker unit with accessory com. ponents. Typical vacuum flow requirements are shown in Table A-11.

The most common type of vacuum puinp used on dairy farms is a rotary vane type. For larger farms, a watersealed or ring-seal is pe of pump is available which can be used to recover the heat of compression in a flush tank. Both types of pumps have about the same efficiency. The ring-seal type is more reliable and more expensive.

Savings in vacuum pumping results from proper sizing and maintenance of the electric motor attached to the pump. See the section on motors in Volume 2 of this guidebook for more information.

Table A-11.

Vacuum Flow Requirements for Milking Systems at a Vacuum Level of One-Half Atmospherle Pressure (7.34 psl)

\begin{tabular}{|c|c|}
\hline Pipolino Syatom Component & $\operatorname{ctm}^{1} /$ unt \\
\hline Milker unit & 6 \\
\hline Vacuum-operated release & 5 \\
\hline Pulsated vacuum line per $10 \mathrm{~h}$ of langhth & 1 \\
\hline Vacuum bulk tank & 0 \\
\hline Milik moler & 1 \\
\hline Sanitary couplings per 20 & 1 \\
\hline Inlats pei 10 & 1 \\
\hline Reserve for regulator & 3 \\
\hline \multicolumn{2}{|c|}{ 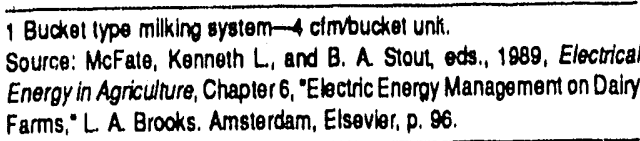 } \\
\hline
\end{tabular}


Table A-12.

$\frac{\text { AGRICULTURAL BRIEF } \# 10}{\text { VENTILATION }}$

\section{DESCRIPTION}

Both natural and mechanical ventilation are used for dairy tarm barns, milking parlors, and millkhouses. Natural ventilation depends on wind pressure, building orientation and construction, and differences between indoor and outdoor temperalure to provide air movement. A dairy larmer who uses electrically powered fans for air movement has much greater control over the environment. Although the power demand for a ventilation system is based upon the hottest and coldest weather of the year, in the interest of economy it is not necessary to design the sysiem for only a few hours of exireme weather. Dairy larm animals can tolerate less than ideal conditions for short periods of time.

Milkhouses usually use positive-pressure fans to avoid drawing in dusty air and odors from the milking parlor or barn. Typiral ventilation energy requirements are listed in Table A-12. For more information on ventilation efflciency improvements, refer io briel \$22 on controlled ventilation under livestock. Recommended ventilation rates for dairy animals are shown in Table A-13.
Electricity Used for Ventlation on Dairy Farms

Equipment or Loud
Ventilta lon: Fans lor stanchion barn

Table A-13.

Recommended Dalry Bam Ventlation Rates'

\begin{tabular}{|c|c|c|c|c|}
\hline \multirow{2}{*}{\multicolumn{2}{|c|}{ Age or Stre }} & \multicolumn{3}{|c|}{ Ventilating R to per Animar } \\
\hline & & \multirow{2}{*}{$\begin{array}{l}\begin{array}{c}\text { Cold } \\
\text { Weather } \\
\text { (cim) }\end{array} \\
15\end{array}$} & \multirow{2}{*}{$\begin{array}{l}\begin{array}{c}\text { Myld } \\
\text { Wenther } \\
\text { (efiii) }\end{array} \\
50\end{array}$} & \multirow{2}{*}{$\begin{array}{c}\begin{array}{c}\text { Hor } \\
\text { Weathor } \\
\text { (ctm) }\end{array} \\
100\end{array}$} \\
\hline Calves & $0-2$ months & & & \\
\hline \multirow[t]{2}{*}{ Heiters } & 2-12 months & 20 & 60 & 130 \\
\hline & $12-24$ months & 30 & 80 & 180 \\
\hline Cows & $(1400 \mathrm{~B})$ & 50 & 170 & 470 \\
\hline
\end{tabular}

1 Although this table of values is used widely throughout the centra U.S. Irom Wisconsin 10 Oklahoma, more otien the rate of ventilation would be one-hall to two-thirds of the bevels listed. Ventilation adjustments should be made to meet bcal housing and climate conditions.

2 An alternative cold-weather rate is one-litteenth of the building volume. An alternative hol weather rate is the bullding volume divided by 1.5 .

Source: McFare, Kenneth L, and B. A. Slour, ods., 1889, Eloctrical Energy in Agriculture, Chapter 6, "Elactric Energy Management on Dairy Farms," L. A. Books. Amsterdam, Elsovier, p. 110. 


\section{MATERIALS HANDLING}

- $\square$

Grain conveyance and food processing are Iwo primary uses of electricity for malerials handling. These, logether with electric chore vehicles, a load growth opportuniIy, are discussed in this section. 
AGRICULTURAL BRIEF\#11 GI.AIN CONVEYANCE

The two most widely used conveyors for moving grains on farms are augers and bucket elevators. There are other specialty conveyors for different kinds of livestock and pouttry leoding systems. For example, belt conveyors are energy efficient but are more expensive than augers and cannot move materlals up steop slopes.

When choosing a conveyance system, consider lactors that affect the efficient use of electricity: the amount of - moisture in the giain, the relative location of storage and feed-processing structures, and the method of unloading storage structures.

\section{TERMS AND DEFNITONS}

AUGER The most widely used type of conveyor on larms is the auger. The auger is a screw conveyor and is used to move shelled corn, small grains, and ground feed. It is inexpensive and portable and may be used for many purposes. Its low efficiency tends to be offset by its low first cost. Moving corn with a high moisture content (25\%) requires more power to drive the auger because the flow characteristics differ from those lor $\mathrm{dry}$ com.

BUCKET ELEVATOR The vertical bucket elevator is more energy elficient and more readily adaptable than the auger to high-volume grain- and tood-handling systems. Bucket systems often move grain to great heights so that the grain flows by gravity into the drying system. Bucket systems can be as much as $65 \%$ more elficient than augers on a per tonitt of lift basis.

\section{COSTS AND BENEFTIS}

Typical ranges for efficiencies are shown below: Bucket system $0.0015-0.002 \mathrm{kWh} / \mathrm{hon} / \mathrm{H}$ of lift Auger system $0.0049-0.0055 \mathrm{kWh} / \mathrm{Non} / \mathrm{t}$ of lift For example, litting and filling a 30-toot-diameter bin to a depth of 8 leet $(\sim 5000$ bushels assuming $40 \mathrm{lb} / \mathrm{bu})$ with a 40 -100 lift would require up to $8 \mathrm{kWh}$ with a bucket system and up $1022 \mathrm{kWh}$ with an auger. 


\section{FEED PROCESSING}

\section{DESCRIPTION}

Two automatic farm leed-processing syslems are com. monly used to mix and process leed for larm livestock and pouttry. The hammer mill is usually used to process leed into finely ground grain for poultry and hogs. Both the hammer and the roller mill are used for processing leed lor dairy or beef caltle. Because the electrical demand of an automalic electric feed-processing system is directly related to the size of the power unit, the smallest unit possible should be chosen.

HAMMER MILL The most popular mill is the hammer mill; because it is simple in construction, grinds dillerent grains well, and is easily adapted to automatic control. It consists of three rows of tree-swinging steel blades that are attached to an electric molor shaft. These blades force or "hammer" tho grains th "ugh openings in a circular screen. The size of openings in the screen (usually between one-eighth and one-hall inch) determines the size of the grind. The energy consumption is higher for mills with smaller screens, which produce more finely ground products. Table A-14 shows typical energy requirements for diflerent grains and screen sizes.

Typically, four to six diflerent grains are introduced into the grinding chamber of the hammer rnill. The grains are measured by volume, most often using an auger.

The hammer mill is available in sizes between 2 and 10 horsepower and in single-phase or three-phase power units.

ROLLER MIL Compared to a hammer mill, a roller mill reduces grain size less. It is othen used to crush high-moisture corn. It consists of two rollers of equal diameter spaced to give the desired crushing effect.
Table A-14.

Electriclty Usod for On-Farm Hammer-MIII Operation

\begin{tabular}{|c|c|c|c|}
\hline \multirow[b]{2}{*}{$\begin{array}{l}\text { Task of } \\
\text { Operdion }\end{array}$} & \multirow[b]{2}{*}{$\begin{array}{c}\text { Prinary Lands } \\
\text { (kW) }\end{array}$} & \multicolumn{2}{|c|}{ 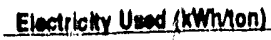 } \\
\hline & & $1 R^{m}$ sereon & $10^{\prime \prime}$ servon \\
\hline $15 \%$ corn & 2.24 & 1.6 & 6.6 \\
\hline $25 \%$ corn & 2.24 & 2.2 & 11 \\
\hline Dry oals & 2.24 & 1.8 & 20 \\
\hline $12.5 \%$ grain sorghum & $\operatorname{lm} 2.24$ & 1.4 & 5.0 \\
\hline
\end{tabular}

Source: McFate, Kenneth L., and B. A. Stout, ods., 1889, Electrica Enorgy in Aoricuture, Chapter 7. Eloctricity Usod In Farmstoad Operations; K. L. McFate. Amsterdam, Elsovier, p. 139.

One roller might be set for wheal or oals and another for shelled corn or milo. When more than one grain is crushed, olther augers or lluted wheols are used to meter the volume of flow. Unlike in the hammer mill, ingredients do not flow into a common crushing chamber. Instead, mixing takes place in a separale compartment atter each grain has been crushed. A disadvanlage of the roller mill is that it cannot be started under a load. The principal advantage of the roller mill is its lower energy requirements on a per-ton basis. Seo Table A-15 for more information.

\section{APPLCABILTY}

All sizes of operations for dairy, swine, and poultry farms.

DEMAND MANAGEMENT OBJECTIVES Strategic conservation, peak clipping

\section{COSTS ANIN BENEFTIS}

Typical swine and pouttry systems cost between $\$ 12,000$ and $\$ 25,000$ for a turnkey operation. 


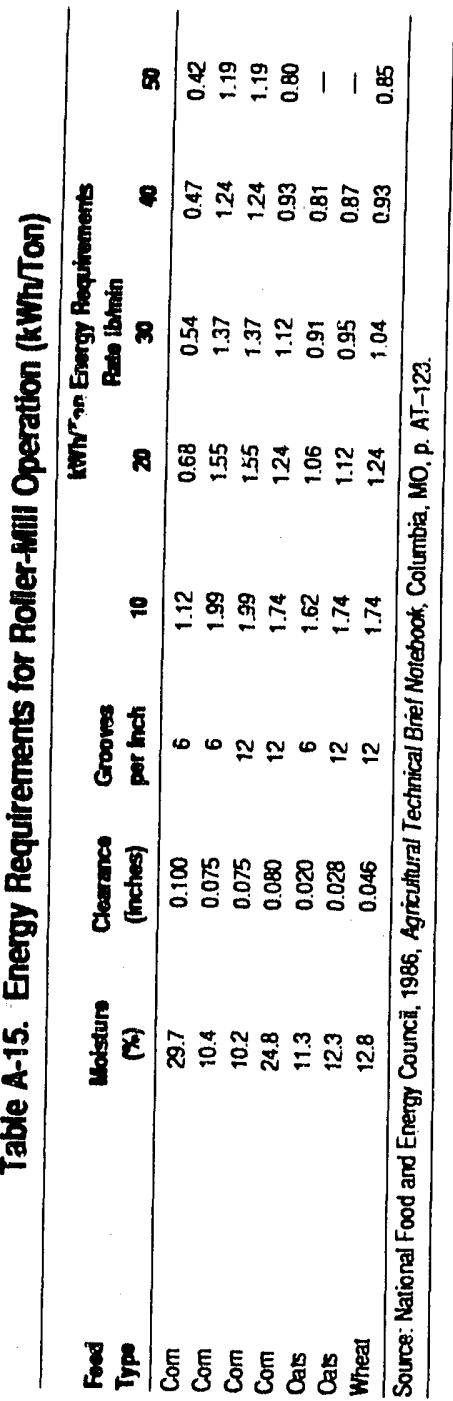

46

\section{ELECTRIC CHORE VEHICLES}

\section{DESCRIPTION}

Farm chores that can be done using a tractor, leed cart, or forklitt account for $24 \%$ of total agricullural vehicle energy use. A shitt trom liquid fuel to electricity for such tasks reprasents a signilicant load growth potential. This load growth potential is further enhanced by the opportunity for off-peak (valley filling) battery charging at low rates. Initially, electric-powered vehicles may cost more than their internal combustion-powered counterparts, but they have some attractive features. Two electricpowered vehicles currently in use are the electric lift truck and the battery-powered chore tractor.

Many Calitornia growers are using electric lift trucks in retrigerated storage buildings because of new battery designs that allow their operation in an eight-hour shlit. Furthermore, compared to propane-powered rucks, electric lift trucks cost less to maintain, do not produce carbon monoxide, make less noise, and do not produce as much waste heat.

In relrigerated storage lacilities, propane-powered units produce nearly three times as much waste heat as electric-powered units. This heat must be removed by the refrineration system. Although the electric vehicle requires energy for charging the batleries, the electrical consumption for battery charging occurs during oll-poak hours. The added cost of removing the heal produced by the propane unit is balanced by the battery-charging costs. The nel effect is that the energy savings and the maintenance cost benelits will pay for the higher initial cosis of the electric vehicle over its life. An electric lift truck costs approximately $\$ 23,000$, or $60 \%$ more than a propane truck. Operating costs tor electric vehicles are estimated at $\$ 1.00$ per hour compared to $\$ 2.50$ per hour for propane trucks. Table A-16 presents a comparison 
Table A-16.

Electric Chore Vehicles: Costs and Benefits

\begin{tabular}{|c|c|c|c|}
\hline & ElectiteDrect' & Electric/Aatton & Dlosal \\
\hline $\begin{array}{l}\text { Energy costs (\$) } \\
\text { Eticiency }(\%)\end{array}$ & $\begin{array}{l}\text { s0.10kWh } \\
77 \%\end{array}$ & $\begin{array}{l}50.05 / \mathrm{KWh} \\
33 \%\end{array}$ & $\begin{array}{l}\$ 1,14 / \mathrm{gal} \\
10 \%\end{array}$ \\
\hline Cosl at axles $(\$ / K W h)^{2}$ & 213 & 25 & 28 \\
\hline Inittal cosis $(\$)^{3}$ & 40,000 & 50,000 & 40,000 \\
\hline $\begin{array}{l}\text { Lifetime (years) } \\
\text { Total annual costs }(\$)^{4}\end{array}$ & $\begin{array}{l}10 \\
13,500\end{array}$ & $\begin{array}{l}10 \\
14,525\end{array}$ & $\begin{array}{l}7 \\
16,390\end{array}$ \\
\hline
\end{tabular}

1 The direct.powered vehicle is assumed to be operaled on peak, the ballery-powered vehicle to be charged ofl peak.

2 Includes cost of batiery replacement lor the electrictbattery option. $360 \mathrm{~kW}(80 \mathrm{ho})$ 4WD or equivalent tractor.

4 Includes capial, energy, anci maintenance costs.

Source: Adapted from McFate, Kenneth L, and B. A. Sloun, eds, 1989 , Eloctrical Energy in Agricuture, Champter 11, "Eloctric Vehicles in Agricuhure, "L. L. Christianson ol al. Amsterdam, Etsevier, pp. 216, 217.

- of the annual cost of operation for diesel and electric chore vehicles.

Battery-powered tractors using a DC electric motor and lead/acid materials are similar in size to conventional tractors with a diesel engine and a fuel tank. Electric tractors with high clearanco and farm implements are commercially available in sizes ranging from 40 to $80 \mathrm{hp}$. They are designed for operating leed wagons, handling manure in outdoor lots, fooding and loading hay and silage, removing snow and debris, and hauling. They can be equipped with a trencher, wire reel, and platform loader. The battery capacity is typically adequate to operate approximately lour hours daily.

\section{APPLCABILTY}

The electric lift truck is applicable for reirigerated storage lacilities, greenhouses, dairy farms, and materials handling. Battery-powered chore tractors are applicable for short-term farmstead use, heavy-use farm jobs, dairy tarms, confinement livestock, and leedlots. DEMAND MANAGEMENT OBJECTIVES Strategic load growth, valley filling
FOR MORE INFORMATION

Roberts, W., 1988, "Electric Powered Vehicles for Storage and Production Facllitles, "Long Island Horticulfure News, Long Island, NY, p. 3.

Natlonal Food and Energy Councll, 1986, Agricultural Technical Briel Notebook, Columbla, MO, p. AT-101. McFate, Kenneth, L., and B. A. Stout, eds., 1989, Electrical Energy in Agriculture, Chapter 11, "Electilc Vehicles in Agriculture," L. L. Christianson el al. Amsterdam, Elsevier, p. 209. 


\section{CROP DRYING \\ - :}

The purpose of grain drying is 10 remove enough moisture so that mold does nol grow in any part of the stored grain. Grain drying is done on cash crop larms as well as on dairy and poultry farms. Although lossil fuels, solar energy, or electric heat may be used for drying, electriclity ls the predominant energy source for moving the al: through the grain. Factors to consider for grain drying include moisture content of the grain, fan characteristics, power required, the amount of air to be moved, and the conditlons of the drying air. Where grain is dried in high-lemperature $\left(180^{\circ} \mathrm{F}-240^{\circ} \mathrm{F}\right)$ balch processes, the primary heal source is LPG.

A typical structure for drying grain is a round, all-metal bin on a concrele base with a perforaled melal lloor above the concrele base. The space between the concrete and the metal, called the plenum, is used to contain the direct air, trom electrically powered tans, that moves through the grain. The roof must have openings to exhaust the most air. The overall efficiency of various all electric grain drying methods is summarized in units of kllowatt hours per bushel of corn per percent moisture removed:

Low-temperalure alr $\quad 0.1-0.2 \quad \mathrm{kWh} / \mathrm{bu} / \%$ Unhealed air $\quad 0.25-0.3 \quad \mathrm{kWh} / \mathrm{bu} / \%$ High-temperature batch grain drying systems have thr. lowest efficlency in terms of Blu per percent moistlire removal. They are also the most labor intensive.

For more informallon, see National Food and Energy Council, 1986, Agricultural Technical Brief Notebook, Columbia, MO, pp. AT-102, A'T-103. 
GRAIN DRYING WITH

\section{LOW-TEMPERATURE ELECTRIC}

\section{DESCRIPTION}

Low-temperafure crop drying uses a combination of air that is healed a fow degreos above amblent fall temperalures and air that is flowing at the rate of 1 to 3 cublo feet por minute to dry a bushel of grain. Resistanco healers are used to raise the temperature $3^{\circ} \mathrm{F}$ to $5^{\circ} \mathrm{F}$. Because the heal is precisely controlled, energy effi. clency is good and the grain quality is better than when high temperatures are used. Because low-lemperature - drying is a long-term process, lans operate continuously from the time that wet grain enters the bin until it is dry 30 to 60 days later. Heat is best used during periods of high humidity, which often exist at night and on loggy or rainy days. Typical tan size is 1102 hp per 1000 bushels of grain. The electric healer should be sized at 1 to $1.5 \mathrm{~kW}$ per lan horsepower. The drying system should start to operate when the average daily temperature reaches $50^{\circ} \mathrm{F}$ to $55^{\circ} \mathrm{F}$ and run until the grain is $\mathrm{dry}$ or the average daily temperature reaches about $30^{\circ} \mathrm{F}$.

Benelits to the utility system include a good load factor during the drying season, com and sorghum drying that does nol add to the summer or winter peak load, and an interruptable load. For the consumer, advantages include lower energy use and cost and a higher-quality product less susceptible to breaking than grain dried at high temperalures.

\section{APPLICABILTTY}

All types of drying bins and crops.

CLIMATE Prolerably dry climates

DEMAND MANACEYENT OBJECTNES Valloy filling, strategic load growth, strategic conservation

\section{COSTS AND BENEFTTS}

Electric heaters cost between $\$ 20$ and $\$ 40$ per kilowath. Cost ol fan motor units ranges from $\$ 100$ to $\$ 200$ per horsepower. Centrifugal lans cost more than axial lans. Fans powered with threo-phase motors cost less than lans powered with single-phase molors, Installallon, wiring and building modifications are addilional expenses.

\section{FOR MORE INFORMATION}

National Food and Energy Council, 1986, Agricultura, Technical Briets Notebook, Columbia, MO, p AT-103. 


\section{GRAIN DRYING WITH} UNHEATED AIR

\section{DESCRIPTION}

Drying grain with unheated air, sometimes called natural air drying, uses the alr's natural capaclty for absorbing moisture. Air with a relative humldity of $60 \%-70 \%$ dries grain to a molsture level that is sale for long-lerm storage at $15 \%$ moisture content. Although high-humidity air removes little moisture, the heat of compression caused by the moving air raises the lemperalure between $1^{\circ} \mathrm{F}$ and $3^{\circ} \mathrm{F}$, thereby reducing the relative humidity. Drying time, from several days to a low weeks, depends on alr flow and weather condllions. Unlike batch or continuous-flow systems, unheated air drying usually takes place in grain storage bins equipped with pertorated floors. Air. llow rates from 110 3 ctm/bushel used to dry grain of $20 \%$ to $26 \%$ molsture require 1 to 3 hp for each 1,000 bushels of grain. Grain depth should not excoed the static pressure limit of the lans:'

Advantages to the customer include low energy require ments for grain drying and high-quality graln.

The utillty benefits from a steady electrical load during October and November. Grain drying is a load that can be interrupted during dally peaks for short periods of time without harming the quality of grain.

\section{APPLCABILTYY}

Farms with adequale storage; cereal grain, wheal, and soybean larms.

\section{CLIMATE Moderale}

DERAND MANAGEMENT OBJECTIVES Strategic conservation, straleglc load growth, peak clipping

\section{COSTS AND BENEFTTS}

Cost of lans is belween $\$ 100$ and $\$ 200$ per horsepower. Centrilugal lans cost more than vane axial lans. Fans powered with threo-phase motors are less expensive than fans powered with single-phase molors. Electrical wiring and installation are additional costs.

\section{FOR MORE INFORMATION}

National Food and Energy Councll, 1986, Agricultural Technical Briet Notebook, Columbla, MO, p. AT-102. 
Table A-17.

CONTROLLED AERATION FOR QUALITY GRAIN

\section{DESCRIPTION}

Controlled aeration is the circulation of air through grain atter normal drying to prevent spoilage. Because grain that is stored during early lail is warmer than grain stored during winter months, there is a temperature gradlent in the stored grain. As cold air is warmed, it pjcks up moisture and moves upward, where the moisture condenses and falls on the iop layers of the grain, and a crusi forms there. Thus, moisture migrates unevenly through the mass of grain to unbalance the previously dried grain. The purpose of controlled aeration is to automalically equalize and maintain the temperature of grain al a level that prevents moisture migratlon and reduces biological and insect activity. The grain temperature should be constant within $10^{\circ} \mathrm{F} 10$ $20^{\circ} \mathrm{F}$ of the coldest stcrage month. The grain should nol be aeraled below $32^{\circ} \mathrm{F}$.

Aeration requires an air-How rele ol one-lenth olm per bushel ol grain to make a complete temperalure change within 120 to 200 hours. Larger-horsepower drying lans decrease the amount of time needed to completely change the temperature. Computerized sensing and control units can ensure accuracy as well as continuous monitoring. Table A. 17 shows the results of a simulation that indicales that controlled aeration of grain can improve by $74 \%$ the pounds of moisture removed per hour ol lan use. 


\section{HAY DRYING}

\section{DESCRIPTION}

High-quallty altalla hay contains about $80 \%$ molsture. The moisture level for sale storage is about $15 \%$. When allalla is allowed to dry in the field, many of the high. protein leaves shatter and are lost. To avold the loss of nutrients in the shattered leaves, hay must be cut at the proper slage of maturity and allowed to partly dry in the field. Then, when the moisture content is about $40 \%$, the hay should be baled or chopped to a length of 410 6 inches. This procedure reduces field drying time to about $50 \%$ of normal and, consequently, reduces losses from intense sun or severe thunderstorms. This parlly cured hay may be placed in a permanent structure where it is completely dried.

Hay drying systems that use large quantitles of heal are usually batch type and dry the hay in one to two days. Natural ajr drying requires a minimum of $2.5 \mathrm{~cm}$ of air for each cubic toot of hay to be dried and lakes 5 to 12 days for a six-lool layer of hay. Drying lime depends on the initlal moisture content of the hay, air-How rale, lemperature and humidity of the air, and the type of equipment used for drying.

Benafits to the larmer of hay drying include better quality lood and up $1020 \%$ greater profit when mar. keted. Utilities benefit from a greater use of electricity.

\section{APRLCABILTTY}

Dairy and speciatty farms; for markel sale. DEMAND MANAGENENT OBJECTIVES Strategic load growth, valloy filling
COSTS AND BENEFTIS

Cosis vary. In Missourl studles, $62 \mathrm{kWh}$ per ton we used to dry $35 \%$ 10 $40 \%$ moislure chopped hay with slotted floor system during a normal summer.

FOR MORE INFORMATION

National Food and Energy Council, 1986, Agricultt Technical Briel Notebook, Columbla, MO, p. AG-12 


\section{LIVESTOCK MEASURES}

\section{- -}

Together, poultry and livestock production account approximately $34 \%$ of the electricity consumed by agricultural sector. Brooding and watering repres major uses of electricity for poultry, swine, and $t$ production. In addition, electrical equipment for light feoving, ventilation, and other uses signilicantly atte the cost of a livestock operation. 


\section{ELECTRIC BROODING}

\section{DESCRIPTION}

Today, both poultry and swine brooding are irequently done with electricity in well-constructed, well-insulated buildings. Buny chicks are confined to a brooding area for the first 25-28 days of their lives. Similarly, newborn swine lie on floors heated as high as $95^{\circ} \mathrm{F}$ for several weeks, atter which they can be transferred to the nursery, where floors are healed 10 about $55^{\circ} \mathrm{F}$ or $60^{\circ} \mathrm{F}$. To allow for elficient use of electricity, brooding can be confined to only a small area of a building (partial house broóding). A large mass of concrete or water, sometimes both, can be heated during the power supplier's oll-peak hours to supply the heat needed for brooding throughout the day.

In an in-floor electric heat system, the cable used to heat the concrete requires a heal density of 4-5 $\mathrm{N}$ per square foot for a well-constructed building. One study in a mild climate showed that a concrete floor without insulation on the underside lost only $4.9^{\circ} \mathrm{F}$ when the heal was turned off for twelve hours after reaching $88^{\circ} \mathrm{F}$. Another common brooding system uses, instead of a heated floor, heat lamps directed at the animals.

The lack of accumulated moisture caused by using electric rather than lossil-fuel heat reduces the cost of ventilation. For comparison, one pound of moisture is produced for each pound of liquid petroleum that is burned. Other advantages include both lower mortality and better leed conversion due to climate control. On the other hand, care must be taken with electric heating to avoid overheating newborn chicks and pigs. Typical energy consumption for swine and poultry brooding is shown in Table A-18.
Table A-18.

Electricity Used for Swine and Poultry Brooding

\begin{tabular}{|c|c|c|}
\hline $\begin{array}{l}\text { Load or Aroa } \\
\text { Inrolusd }\end{array}$ & Electricily Uned & Commonts \\
\hline $\begin{array}{l}\text { SWWE BROOOING } \\
\text { Cable, in tbor } \\
400 W \text { per pen }\end{array}$ & $\begin{array}{l}50-100 \mathrm{kWh} \\
\text { per sow litter }\end{array}$ & $\begin{array}{l}\text { Lower use in tall, } \\
\text { higher use in winter }\end{array}$ \\
\hline $\begin{array}{l}\text { Cable, in floor } \\
\text { 3oow per pen }\end{array}$ & $19 \mathrm{kWh}$ per sow litter & Southern climate \\
\hline $\begin{array}{l}\text { Commercial pads } \\
\text { 300W per pen }\end{array}$ & $\begin{array}{l}\text { 40-120 kWh } \\
\text { per sow litter }\end{array}$ & $\begin{array}{l}\text { Lower use in fall, } \\
\text { higher use in winter }\end{array}$ \\
\hline $\begin{array}{l}\text { Heal lamps } \\
250 \text { W per pen }\end{array}$ & $\begin{array}{l}6 \text { hWWiday } \\
\text { por sow litter }\end{array}$ & Units on continuously \\
\hline $\begin{array}{l}\text { POULTRY BROODING } \\
1560 \text { hover Units }\end{array}$ & $\begin{array}{l}\text { Go-44 kWh } \\
\text { per } 100 \text { birds }\end{array}$ & $\begin{array}{l}\text { Spririg-summer } \\
\text { broods, poor housing }\end{array}$ \\
\hline & $\begin{array}{l}25-60 \mathrm{kWh} \\
\text { per } 100 \text { birds }\end{array}$ & $\begin{array}{l}\text { Fall-winter broods, } \\
\text { poor housing }\end{array}$ \\
\hline & $46 \mathrm{kWh}$ per 100 birds & $\begin{array}{l}\text { November-January } \\
\text { broods, insulated } \\
\text { housing }\end{array}$ \\
\hline Quartz heat brooders & $34 \mathrm{kWh}$ per 100 birds & $\begin{array}{l}\text { Well-insulated }(R \cdot 13) \\
\text { windowless } \\
\text { lest housa }\end{array}$ \\
\hline $\begin{array}{l}\text { Space hoaters } \\
\text { (supplemental) }\end{array}$ & $5 \mathrm{kWh}$ per 100 birds & $\begin{array}{l}\text { Well-insulated }(R \cdot 13) \\
\text { windowless } \\
\text { test house }\end{array}$ \\
\hline \multicolumn{3}{|c|}{ 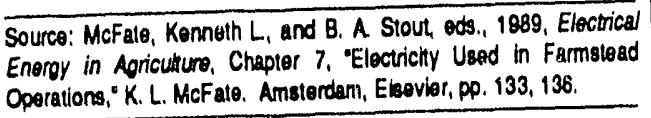 } \\
\hline
\end{tabular}




\section{APPLCABILTYY}

CLIMATE Mild winter climates; colder winter climaies where an overall $U$ value of 0.1 Btum- $\mathrm{H}^{2} .{ }^{\circ} \mathrm{F}$ is mel by the building shell.

DEMAND MANAGENENT OBJECTNES Valley filling, strategic growth

\section{FOR MORE INFORMATION}

National Food and Energy Council, 1986, Agricultural Technical Brief Notebook, Columbia, MO, p. AT-124.

Table A-19.

\section{Electric Brooding: Costs and Benefits}

\begin{tabular}{|c|c|}
\hline $\begin{array}{l}\text { Brooding } \\
\text { System }\end{array}$ & $\begin{array}{c}\text { Annus } \cos A^{1} \\
(\$)\end{array}$ \\
\hline $\begin{array}{l}\text { Conventional gas LP } \\
\text { Conventional olectric } \\
\text { Electric cable in-floor (of peak) } \\
\text { PVC in-floor } \\
\text { PVC on-floor }\end{array}$ & $\begin{array}{l}2550 \\
6470 \\
1290 \\
1180 \\
1230\end{array}$ \\
\hline \multicolumn{2}{|c|}{ 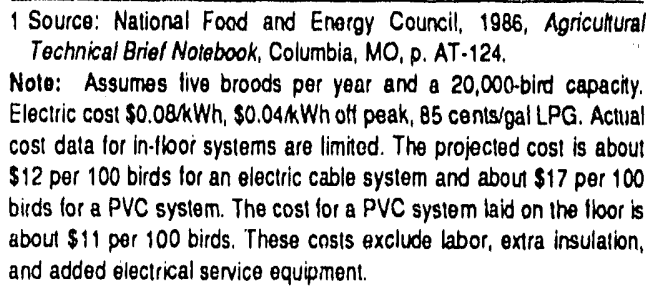 } \\
\hline
\end{tabular}

AGRICULTURAL BRIEF\#19

\section{DUAL FUEL FOR} LIVESTOCK BROODING

\section{DESCRIPTION}

Dual fuel means that two fuels are used to provide heat for brooding. Electricity is the primary energy source used during oft-peak hours $80 \%-95 \%$ of the time. LP gas is the usual secondary fuel used during on-peak hours about $5 \%-20 \%$ of the time. The objective is 10 avoid paying demand prices for electrictly. Swittching between systems can be remotely controlled by the utility using radio or power-line carrier systems. Wellconstructed and well-Insulated brooding houses are required.

More opportunity for dual fuel exists for swine production than for poultry production (located primarily in the warm southeastern U.S.), athough one Minnesola turkey producer reduced electricity costs by $30 \%-44 \%$ using dual fuel and saved $\$ 700$ during 1986. See Table A-20 for savings obtained by three Minnesota farms.

\section{APPLCABILTYY}

CLIMATE Winter weather conditions DEMAND MANAGEMENT OBJECTNES Peak clipping, valley filling, strategic load growth 


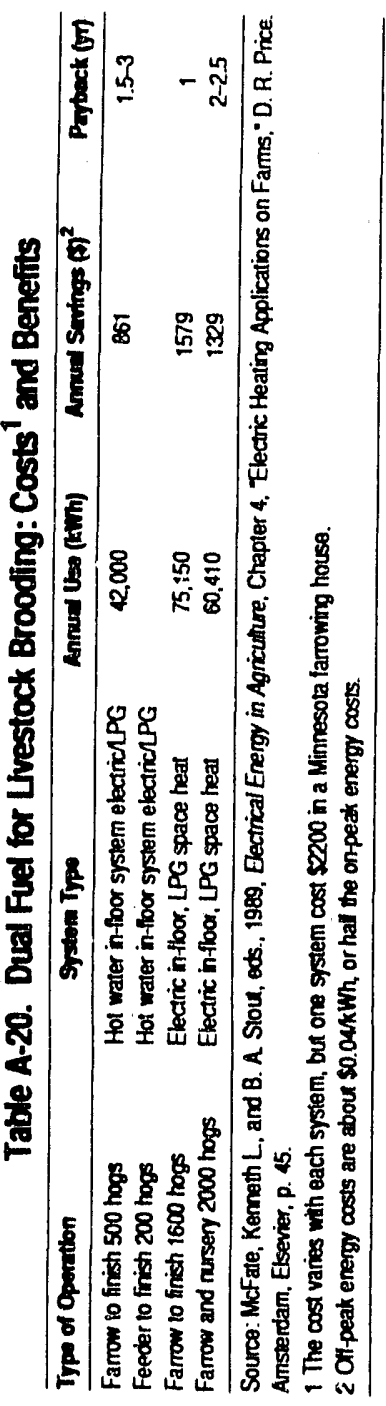

66

\section{WATERERS}

\section{DESCRIPTION}

The amount of water consumed by livestock directly aflects their health, ability to digest leed, body lissue bullding, and body heat regulation. In lowa, researchers found that hogs with ice-tree water gained 0.24 lbs more per day than those in pens where water was not readily available. Also, lowa studies showed that dairy cows with accoss to automatic waterers drank. $18 \%$ more water and produced $3.5 \%$ more milk than cows watered twice a day. When livestock is fed modern rations that include high protein, an increased water intake is necessary for good health. In warm to hol climates, livestock (including poultry) use more than the usua amount of water to regulate body temperature. No onls do waterers improve production, but they also reduce mortality. Typical energy consumption lor livestu,st waterers is shown in Table A.21.

Although the size and shape of walerers varies depend ing upon the type of livestock, the basic design princi ples remain the same. One way to prevent waler from ireezing is to apply electric heal. For examiple, heailn! elements on some waterers are immersed in thr drinking water storage chamber so that hsal is trans ferred directly to the water. Outside waterers must $b_{1}$ well insulated with 1.5 inches or more of insulation 1 prevent freezing. Adjustable temperature control wi minimize energy use because water should not be ovel heated. The water surlace must be readily avallable I livestock, but hinged lids or lightweight floats on th water surface may be used to reduce heat loss. Hog can use a fountain-type waterer that delivers water 0 demand and eliminales the standby losses of troug systems. 
Table A-21.

Electriclty Used tor LUvestock Watering

\begin{tabular}{|c|c|c|}
\hline Loud or Ares & Electrlethy Uand & Comments \\
\hline Ouside location & $\begin{array}{l}5-10 \mathrm{kWh} \text { per thog } \\
\text { markeled }\end{array}$ & $100-200$ b hogs \\
\hline Inside location & $\begin{array}{l}2-3 \mathrm{kWh} \text { per hog } \\
\text { marketed }\end{array}$ & $100-200$ to hogs \\
\hline Pumping distribution & $\begin{array}{l}3 \mathrm{kWh} \text { per hog } \\
\text { marketed }\end{array}$ & One 2,000-hog larm \\
\hline $\begin{array}{l}\text { Canlo waterer } \\
\text { (outside) }\end{array}$ & 6-7.5 kWh cowtyos & \\
\hline Pumping/distribution & $0.35 \mathrm{kWh}$ per $220 \mathrm{bs}$ & Four-farm avorago \\
\hline
\end{tabular}

Source: McFate, Kenneth L, and B. A. Stout, eds, 1989, Electrical

Energy in Agricuture, Chapter 7. "Electricity used in Farmstead - Operations," K. L. McFate. Amstordam, Elsevier, pp. 131, 132, 134.

Another method to prevent livestock water from freezing uses continuous-flow waterers that either recirculate water or dispose of the excess water in a nonrecirculating system. In this method, healing elements are not immersed in the drinking bowl or cup. Electricity uses include circulating pumps, electric heaters to heat the supply tank, and electric trace heaters to prevent pipe freezing.

\section{APPLCABILTYY}

CLIMATE All climates, especially in cold winter climales where freezing is likely to occur

DEMAND MANAGENENT OBJECTIVES Strategic conservation, strategic load growth
AGRICULTURAL BRIEF\#21

\section{EARTH-TUBE HEAT-EXCHANGE VENTILATION SYSTEMS}

\section{DESCRIPTION}

Earth-tube heat-exchange ventilation syslems use the relatively uniform temperature of the earth at depths of 6-12 teet to supplement heating in the wiriter and cooling in the summer for livestock bulldings. During the year, the temperature at a depth of 6 foet varies only about $10^{\circ} \mathrm{F}$ and at a depth of 12 feet it varies only aboul $6^{\circ} \mathrm{F}$. Studies have shown that atter passing through the heat-exchanger tube, the winter outside air will enter a building $25^{\circ} \mathrm{F}$ to $30^{\circ} \mathrm{F}$ warmer, and in the summer $25^{\circ} \mathrm{F}$ to $30^{\circ} \mathrm{F}$ cooler, than ambient temperatures.

Actual design ol an earth-tube heal exchanger depends on ventilation requirements, the area tree tor pipe burial and soil characteristics. Earth-tube heal exchangers pertorm best in wet clay soll because of their high hea' conductivity. Success ol systems in deep sandy soils is questlonable. When the earth-tube heat-exchange sys. tem is used with electric heating for livestock facilities peak demand is reduced.

\section{APPLICABILTTY}

Livestock confinement.

DEMAND MANAGEMENT OBJECTIVES Strategi conservation, peak clipping, strategic load growth

\section{FOR MORE INFORMATION}

National Food and Energy Council, 1986, Agricultur: Tochnical Briot Notebook, Columbia, MO, p. AT-126. 
Table A-22.

Earth-Tube Heat-Exchange Ventlation Syztems: Costs and Benefits

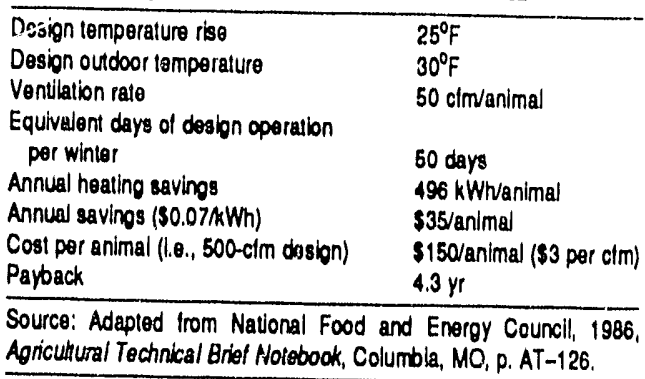

CONTROLLED VENTILATION

Controlled livestock ventilation uses propeller fans with electric motors to exchange normally clean outside ali with dust-, molsture-, and odor-laden air in a llvestock building. During cold periods, heat must be added to this process. During warm weather, air exchange is used to control the temperature rise in buildings that is caused by accumulation of livestock body heal

In livestock structures, it is recommended that a com. bination of small and large tans be used to provide moisture and odor control in the winter as well as it cool during warmer months. During the coldest weather the ventilation system must remove most of the mols ture produced but as little heat as possible. Air-to-al heal exchangers are available to recover heal from thr warm moist air exhausted from the building. Will elficiencies in the $50 \%-70 \%$ range, these units havi five-year paybacks.

The four basic components for livestock ventilatio systems are air inlels, air inlel controls, motor-drivel lans, and lan molor controls. Although the driving foro is the electrically powered tan, the air inlets must $b$ carefully controlled to evenly distribute the tresh al Controls are used to keep the amount of inlet openin matched to the number of tans running. For direct-driv fans, a 10 to $12 \mathrm{ctm} W$ performance is good; for bel drive fans, 18 to $29 \mathrm{ctm} M$ is considered good. Bol 115-V and 230-V single-phase power are common used; the higher voltage is preterred to reduce wirin cost and line loss. Threo-phase power is less expensiv than single-phase power, tort it is only available to limited number of larmsteads. 
Advantages to the utility's customer include reducod labor requirements; lower heal bills; healthier livestock and less medicarion; more intense lacility use; faster weight gains; and increased production of meat, eggs, and milk. Also, the utility can expect predictable loads. One disadvantage to the utility is the peak demand crated atter a power outage. Fans should be reaclivalond in stages to reduce this peak.

\section{APPLICABILTTY}

Dairy barns and milking rooms; other livestock confinement.

DEMAND MANAGEMENT OBJECTIVES Strategic conservation

\section{COSTS AND BENEFTIS}

Cosis vary, In one example, a system with a 200-pig nursery would cost about $\$ 2000 ; 50 \%$ of this cost would be for lans and tan controls. Costs vary depending on quality of components, whether or nol corrosion-resistant components are required, sophistication of controls, and transportation requirements. Air-10-air heal exchangers cosl $\$ 2-\$ 6$ per clm.

\section{FOR MORE INFORMATION}

National Food and Energy Council, 1986, Agricultural Technical Briets, Columbia, MO, p. T-106.

Northeast Regional Agricultural Engineering Service, 1979, "Choosing and Maintaining Ventilation Fans," Cornell University, NY, FS 21.

\section{EVAPORATIVE COOLING SYSTEMS}

\section{DESCRIPTION}

In areas of relatively low humidity, evaporative cooling systems use heat from ambient air to vaporize water and thus cool the air. With the trend toward tightly insulated, well-constructed livestock bulldings, environmental control is necessary. Evaporative cooling helps to reduce poultry mortality caused by heat in major broller- and egg-producing areas. Swine producers also cool structures with evaporative coolers.

For a utility, evaporative cooling of liveslock buildings is a strategic load growth opportunity. One northeastern structure used $82 \mathrm{kWh} /$ year per 100 birds for ventilation. For the customer, reduced mortality can result in a payback that varies from a fow days to several years depending on high summer temperalures.

\section{APPLICABILTYY}

Poultry and swine operations.

CLIMATE SUmmer months, dry climates DEMAND MANAGEMENT OBJECTNES Valley filling, stralegic load growth

\section{COSTS AND BENEFTIS}

The cost is variable. In one southeastern poultry operation, cost was about $\$ 0.35$ per bird housed. Because of high pressure against which fans must operate and the extra energy used by the water circulation pump, the cost of operating the evaporative cooling system may be as much as $25 \%$ grealer than dry air ventilation systems during high-temperalure periods.

FOR MORE INFORMATION National Food and Energy Councll, 1986, Agricullural Tochnical Briets Notebook, Columbia, MO, p. AT-135. 

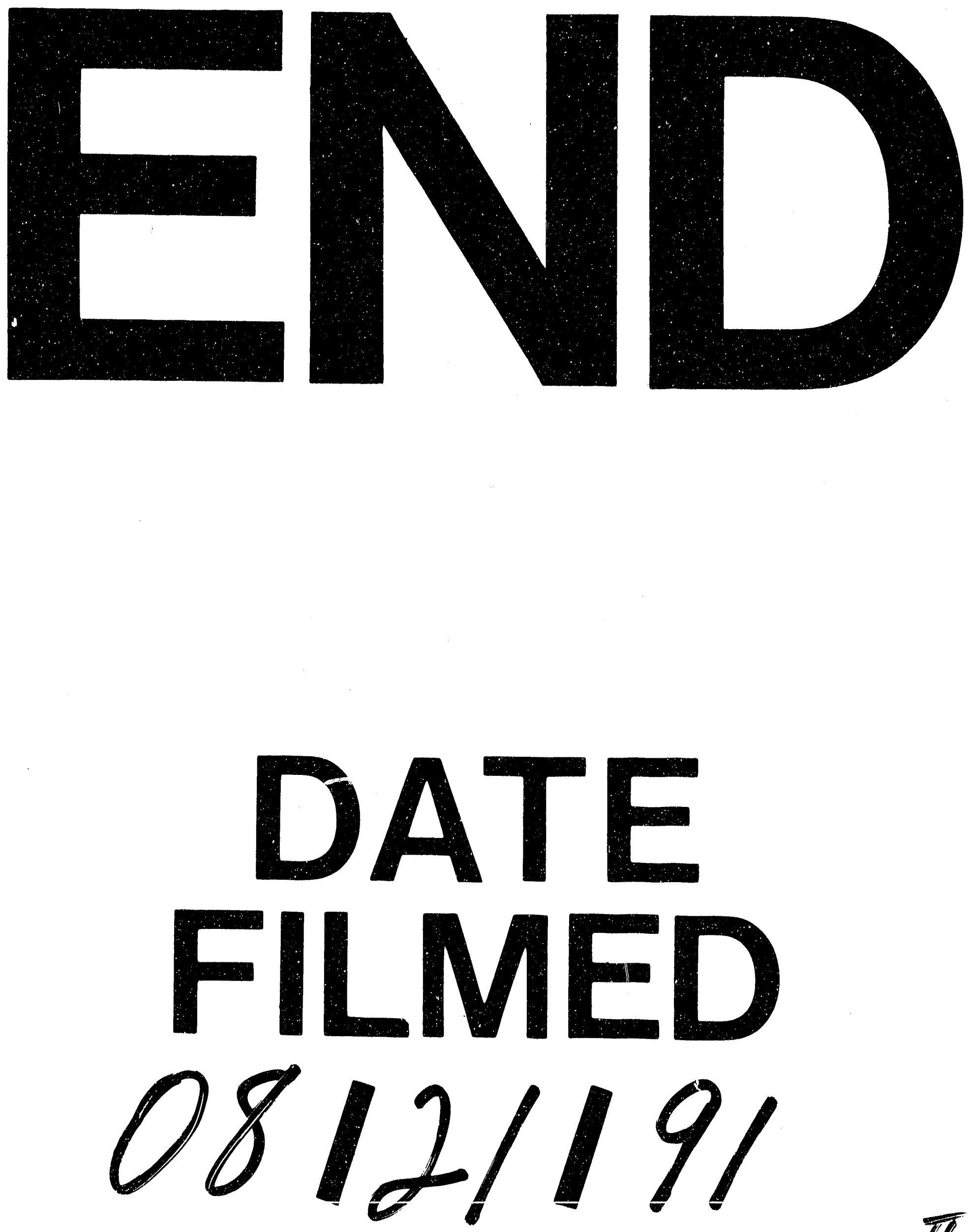

II 
